\title{
STRATEGI PENGHIMPUNAN DANA PIHAK KETIGA PADA PT. BANK RAKYAT INDONESIA (PERSERO),TBK. UNIT CIBINONG KANTOR CABANG CIBINONG GRAHA INDA
}

\author{
ALDI ALVIAN ERLANDO RANDA \\ EDY SAFNI ROSA \\ RATIH PUSPITASARI
}

\begin{abstract}
ABSTRAK
Perkembangan dunia usaha tidak dapat dilepaskan dari perkembangan sektor usaha perbankan yang mempunyai fungsi pokok sebagai agen pembangunan maupun financial intermediary, yang merupakan salah satu pendukung usaha pembangunan tersebut. Dalam mendukung usaha pembangunan bank membantu menghimpun dana dan menyalurkan dana agar dalam pelaksanaan penghimpunan dana dapat berjalan dengan baik maka diperlukan sebuah strategi agar pengelola usaha dapat berjalan dengan lancar.

Tujuan diadakannya strategi penghimpunan yaitu untuk mengetahui bagaiman strategi yang dilkakukan Bank BRI unit Cibinong dalam menghimpun dana pihak ketiga, faktor-faktor apa saja yang mempengaruhi strategi penghimpunan tabungan.

BRI unit Cibinong telah melaksanakan strategi yang sesuai dengan ketetapan BRI pusat mulai dari strategi pemasaran seperti melalui periklanan, website dan publisitas, Adapun strategi alternatif yang diterapkan oleh BRI unit Cibinong. Faktor-faktor yang mempengaruhi strategi pemghimpunan tabungan adalah strategi produk, strategi harga dan strategi lokasi.
\end{abstract}

Kata Kunci : Strategi, Penghimpunan Tabungan 


\section{BAB I \\ PENDAHULUAN}

\subsection{Latar Belakang}

Pada era globalisasi ini industri perbankan merupakan industri yang mengalami perkembangan yang cukup pesat, baik dari sisi volume usaha, mobilisasi masyarakat maupun pemberian kredit. Dengan semakin banyaknya jumlah bank dan lembaga keuangan bukan bank membuat persaingan dalam menarik minat masyarakat untuk menyimpan uang nya di bank semakin ketat. Hal ini mempengaruhi pola dan strategi manajemen perbankan untuk lebih kreatif dan inovatif dalam mengembangkan dan memperoleh sumber-sumber dana baru.

Lembaga keuangan setiap perusahaan yang kegiatan usahanya berkaitan dengan bidang keuangan kegiatan usaha lembaga keuangan bank dapat berupa menghimpun dana dengan menawarkan berbagai skema, menyalurkan dana sekaligus, dimana kegiatan usaha lembaga keuangan diperuntukkan bagi investasi perusahaan, kegiatan konsumsi, dan kegiatan distribusi barang dan jasa.

Sumber dana bank yang berasal dari modal sendiri dan cadangan modal hanya sebesar $7 \%$ sampai dengan $8 \%$ dari total aktiva bank,pentingnya sumber dana dari masyarakat luas merupakan sumber dana yang paling utama bagi bank, dana yang berhasil dihimpun oleh bank justru akan menjadi beban apabila tanpa adanya alokasi untuk tujuan yang produktif berdasarkan kebutuhan itu dan juga untuk memperoleh penerimaan bank dalam rangka menutup biaya-biaya lain serta mendapatkan keuntungan dengan mengalokasikannya untuk asset produktif antara lain yaitu kredit, investasi, cadangan likuiditas, serta aktiva tetap dan inventaris.

Dana pihak ketiga (simpanan) yang dijelaskan dalam tentang perbankan adalah dana yang dipercayakan oleh masyarakat kepada bank berdasarkan perjanjian penyimpanan dana dalam bentuk giro, deposito, sertifikat deposito, tabungan, dan atau bentuk lainnya yang dipersamakan dengan itu.

Dana pihak ketiga adalah dana yang berasal dari masyarakat luas yang merupakan sumber dana terpenting bagi kegiatan operasional suatu bank dan merupakan ukuran keberhasilan bank jika mampu membiayai operasionalnya dari sumber dana ini khususnya pada produk tabungan. 
Sumber dana ini merupakan sumber dana terpenting bagi kegiatan operasional bank dan merupakan ukuran keberhasilan bank jika mampu membiayai operasionalnya dari sumber dana ini. Sumber dana yang dimaksud adalah tabungan yaitu simpanan yang penarikannya hanya dapat dilakukan menurut syarat-syarat tertentu yang disepakati, tetapi tidak dapat ditarik dengan cek, bilyet giro, dan atau alat lainnya yang dipersamakan dengan itu.

Beberapa lembaga keuangan mungkin mempunyai tujuan yang sama, akan tetapi strategi yang digunakan untuk mencapai tujuan tersebut sudah tentu berbeda. Pada umumnya semua jajaran manajemen suatu lembaga keuangan akan selalu membuat rencana-rencana yang baik dan tepat. Akan tetapi penentuan berhasil atau tidaknya rencana tersebut sangat tergantung pada pelaksanaan dari semua strategi yang telah dibuat. Maka jelaslah bahwa masalah strategi bagi suatu lembaga keuangan sangatlah penting. Sebab strategi tersebut merupakan penentuan tercapainya tujuan yang telah direncanakan.

PT. Bank Rakyat Indonesia Persero Tbk. (BRI) adalah salah satu bank terkemuka di Indonesia yang tersebar luas diseluruh wilayah Indonesia dan memiliki unit kerja yang sangat luas, sampai pada dearah yang terpencil. Salah satu cabang PT. Bank Rakyat Indonesia Persero Tbk. (BRI) adalah Bank BRI Unit Cibinong.

Bank BRI berfokus pada kebutuhan nasabah yang dipertegas dalam strategi menghadapi perkembangan industri perbankan Indonesia yang semakin kompetitif. BRI berupaya untuk menyempurnakan layanan nasabah maupun kenyamanan bertransaksi telah menjadi prioritas Bank BRI dalam menjalani kegiatan operasionalnya.

Strategi promosi penting dilakukan oleh bank dalam menarik minat masyarakat untuk menyimpan uangnya di bank dalam bentuk tabungan, deposito dan giro karena dana dari masyarakat dapat menambah modal bank untuk pemberian kredit selain itu juga untuk menjaga kesehatan bank, tujuan dari promosi adalah untuk menginformasikan,membujuk, serta mengingatka kepada pelanggan tentang produk perbankan dan bauran pemasarannya. Dengan adanya promosi diharapkan produk yang dikeluarkan oleh bank dapat diterima oleh masyarakat.dalam mencari sumber sumber dana pihak ketiga bank harus mempertimbangkan beberapa factor seperti kemudahan untuk memperolehnya , 
jangka waktu sumber dana serta biaya yang harus dikeluarkan untuk memperoleh dana tersebut.

Dalam praktiknya bank menggunakan 3 macam sarana promosi yang dapat digunakan untuk menarik minat masyarakat luas untuk mempromosikan produk maupun jasanya yaitu pertama melalui advertising (periklanan), sales promotion (promosi penjualan), dan publicity (publisitas) berdasarkan uraian di atas maka penulis mengambil judul "STRATEGI PENGHIMPUNAN TABUNGAN BANK RAKYAT INDONESIA PERSERO TBK. (BRI) UNIT CIBINONG"

\subsection{Identifikasi Masalah}

Berdasarkan uraian dalam pembahasan tugas akhir ini, maka penulis mengidentifikasikan sebagai berikut :

1. Bagaimana strategi yang dilakukan untuk menghimpun dana dari masyarakat dalam bentuk tabungan.

2. Faktor-faktor apa saja yang mempengaruhi strategi penghimpunan tabungan.

\subsection{Maksud dan Tujuan}

Adapun maksud dan tujuan dari pembahasan yang telah penulis teliti, adalah sebagai berikut :

1. Untuk mengetahui strategi menghimpun dana dari masyarakat dalam bentuk tabungan.

2. Untuk mengetahui faktor-faktor apa saja yang mempengaruhi strategi penghimpunan tabungan.

\subsection{Waktu dan Tempat Pelaksanaan Magang}

Tempat pelaksanaan magang yaitu PT. Bank Rakyat Indonesia (Persero), Tbk Unit Cibinong yang beralamat di Jl. Raya Bogor Km 45 Cibinong. Jangka waktu pelaksanaan magang yaitu selama 2 (dua) bulan mulai dari tanggal 09 Maret 2015 sampai dengan tanggal 08 Mei 2015. Jam kerja yang berlaku yaitu hari Senin - Jum'at pukul 08.00 WIB sampai dengan 15.00 WIB. 


\section{BAB II \\ TINJAUAN PUSTAKA}

\subsection{Bank}

\subsubsection{Pengertian Bank}

Menurut Dictionary of Banking and Financial Service by Jerry

Rosenberg:

Bank adalah lembaga yang menerima simpanan giro, deposito, dan membayar atas dasar dokumen yang ditarik pada orang atau lembaga tertentu, mendiskonto surat berharga, memberikan pinjaman dan menanamkan dananya dalam surat berharga.

UU No. 10 Tahun 1998 tentang Perbankan menyatakan bahwa:

Bank adalah badan usaha yang menghimpun dana dari masyarakat dalam bentuk simpanan dan menyalurkannya kepada masyarakat dalam bentuk kredit dan atau bentuk - bentuk lainnya dalam rangka meningkatkan taraf hidup rakyat banyak.

Ikatan Bankir Indonesia ( 2013 : 6 ) berpendapat bahwa bank adalah : "Suatu badan usaha yang menghimpun dana dari masyarakat dalam bentuk simpanan dan menyalurkannya kepada masyarakat kembali dalam rangka meningkatkan taraf hidup rakyat banyak". Selain itu Kasmir ( 2014 : 3) mengatakan pengertian bank adalah : "Lembaga keuangan yang kegiatan usahanya adalah menghimpun dana dari masyarakat dan menyalurkan kembali dana tersebut ke masyarakat serta memberikan jasa bank lainnya".

Definisi lain dari bank menurut Howard D. Crosse dan George J. Hemple adalah :

Suatu organisasi yang menghubungkan usaha manusia dan sumber sumber keuangan untuk melaksanakan fungsi bank dalam rangka melayani kebutuhan masyarakat dan untuk memperoleh keuntungan bagi pemilik.

Sementara menurut F.E. Perry pengertian bank adalah :

Suatu badan usaha yang transaksinya berkaitan dengan uang, menerima simpanan (deposit) dari nasabah, menyediakan dana atas setiap penarikan, melakukan penagihan cek - cek atas perintah nasabah, memberikan kredit, dan atau menanamkan kelebihan simpanan tersebut sampai dibutuhkan untuk pembayaran kembali. 
Memperhatikan pengertian diatas dapat dikatakan bahwa bank adalah sebuah badan usaha lembaga keuangan yang kegiatan usahanya menerima dan menghimpun dana dari masyarakat yang kelebihan dana kemudian menyalurkan kembali ke masyarakat yang membutuhkan dana dalam bentuk kredit. Dalam penerapannya bank juga memberikan jasa - jasa untuk melakukan lalu lintas pembayaran serta memberikan pelayanan jasa yang terbaik demi kenyamanan dan loyalitas nasabah. Kegiatan usaha yang dilakukan bank bertujuan untuk meningkatkan kesejahteraan masyarakat dan taraf hidup rakyat banyak.

\subsubsection{Jenis - Jenis Bank}

Jenis bank berdasarkan Undang - Undang Perbankan No. 7 tahun 1992 yang telah direvisi menjadi UU No. 10 tahun 1998 membagi bank menjadi dua jenis yaitu :

a) Bank Umum, yaitu bank yang melaksanakan kegiatan usahanya secara konvensional dan atau berdasarkan prinsip syariah yang dalam kegiatannya memberikan jasa lalu lintas pembayaran. Bank Umum melaksanakan seluruh fungsi perbankan baik dalam menghimpun dan menerima dana dari masyarakat, menempatkan dan menyalurkan dana, serta memperlancar lalu - lintas pembayaran giral.

b) Bank Perkreditan Rakyat, yaitu bank yang melaksanakan kegiatan usahanya secara konvensional dan atau berdasarkan prinsip syariah yang dalam kegiatannya tidak memberikan jasa layanan lalu lintas pembayaran. BPR seperti bank umum namun memiliki keterbatasan dalam lingkup wilayah operasinya misalnya hanya dalam kabupaten saja. BPR tidak diperbolehkan mengeluarkan cek maupun bilyet giro sehingga BPR tidak boleh mengikuti kliring dan tidak terlibat dalam transaksi giral. BPR hanya boleh menghimpun dana menggunakan produk tabungan dan deposito.

1. Jenis Bank Dilihat dari Fungsinya

a) Bank Komersial, yaitu bank yang dalam pengumpulan dananya terutama menerima deposito dalam bentuk giro maupun deposito berjangka dan dalam usahanya lebih kepada memberikan kredit jangka pendek.

b) Bank Pembangunan, yaitu bank yang dalam mengumpulkan dananya lebih menggunakan produk deposito berjangka dan atau mengeluarkan 
kertas berharga jangka menengah dan jangka panjang. Bank ini juga dalam usahanya lebih memberikan kredit jangka menengah dan jangka panjang di bidang pembangunan. Bank pembangunan di Indonsia terdiri dari Bank Pembangunan Pemerintah, Bank Pembangunan Daerah, Bank Pembangunan Swasta, dan Bank Pembangunan Koperasi.

c) Bank Tabungan, yaitu bank yang dalam pengumpulan dananya terutama menerima deposito dalam bentuk deposito tabungan dan dalam usahanya lebih kepada memperbungakan dananya dalam kertas berharga yang dimiliki. Bank Tabungan ini di Indonesia terdiri dari Bank Tabungan Negara, Bank Tabungan Swasta, dan Bank Tabungan Koperasi.

2. Jenis Bank Berdasarkan Kepemilikan

a) Bank Pemerintah Pusat, yaitu Bank Komersial, Bank Tabungan atau Bank Pembangunan yang mayoritas kepemilikannya berada di tangan pemerintah pusat.

b) Bank Pemerintah Daerah, yaitu Bank Komersial, Bank Tabungan atau Bank Pembangunan yang mayoritas kepemilikannya berada di tangan pemerintah daerah.

c) Bank Swasta Nasional, yaitu bank yang dimiliki oleh Warga Negara Indonesia.

d) Bank Asing, yaitu bank yang mayoritas kepemilikannya dimiliki oleh pihak asing.

e) Bank Swasta Campuran, yaitu bank yang dimiliki oleh swasta domestik dan swasta asing.

3. Jenis Bank Berdasarkan Kegiatan Devisa

a) Bank Devisa, yaitu bank yang dalam kegiatan usahanya memperoleh ijin dari Bank Indonesia untuk menjual, membeli, dan menyimpan devisa serta menyelenggarakan lalu lintas pembayaran dengan pihak luar negeri. Contoh bank devisa di Indonesia : Bank BNI 46, Bank BCA, Bank CIMB Niaga.

b) Bank Non Devisa, yaitu bank yang dalam kegiatan usahanya tidak memperoleh ijin dari Bank Indonesia untuk menjual, membeli, dan menyimpan devisa serta menyelenggarakan lalu lintas pembayaran 
dengan pihak asing. Contoh bank non devisa di Indonesia: Bank Jasa Jakarta, Bank Kesejahteraan Ekonomi, Bank Mayora.

\subsubsection{Kegiatan Usaha Bank}

Sesuai dengan UU tentang Perbankan di Indonesia, kegiatan usaha bank pada dasarnya hanya ada dua yaitu kegiatan menghimpun dana dan menyalurkan dana masyarakat. Bentuk kegiatan dalam menghimpun atau menerima dana dari masyarakat yang dapat dilakukan berupa giro, tabungan, dan deposito. Sedangkan untuk bentuk kegiatan menyalurkan dana ke masyarakat dapat dilakukan dalam bentuk pemberian kredit. Bank juga bisa menyalurkan dana yang berhasil dihimpun ke sektor investasi seperti penempatan investasi jangka pendek berupa surat berharga jangka pendek.

Segala kegiatan usaha yang dilakukan oleh bank hanya bleh dijalankan atas ijin dari Bank Indonesia selaku bank sentra di Indonesia. Bank di Indonesia juga harus menjalankan setiap kegiatan usahanya sesuai dengan regulasi yang sudah ditetapkan oleh Bank Indonesia.

Menghimpun dana dari masyarakat bukanlah hal yang mudah dan gampang bagi bank. Bank harus bisa menarik minat dari masyarakat luas agar mau menyimpan dana mereka di bank. Masyarakat akan melihat kredibilitas bank tersebut sebelum mereka menyimpan dana mereka. Kepercayaan masyarakat terhadap bank menjadi komponen yang sangat penting di dalam usaha bank menghimpun dana masyarakat. Bank yang memiliki kredibilitas, kesehatan bank, dan kemampuan financial yang baik serta meningkat akan sangat dipercaya masyarakat. Bank juga harus menjadi mitra pembangunan yang bermanfaat bagi masyarakat. Bank harus mampu meyakinkan masyarakat bahwa dana yang tersimpan akan memberikan banyak manfaat dan keuntungan dengan risiko seminimal mungkin. Dan yang tidak kalah penting bank harus memberikan layanan sebaik mungkin dalam memberikan pelayanan kepada masyarakat. Bank harus mampu memberikan solusi kemudahan transaksi bagi nasabah yang aman, cepat, tepat, dan terpercaya.

Selain menghimpun dana, bank juga melakukan kegiatan untuk menyalurkan dana ke masyarakat melalui kredit. Kredit menjadi salah satu faktor dalam perkembangan perekonomian di suatu negara. Kredit sangat dibutuhkan oleh masyarakat sebagai pelaku ekonomi. Dengan adanya kredit banyak perusahaan yang akan melakukan ekspansi perusahaan mereka sehingga 
semakin maju dan berkembang. Situasi ini berdampak bagi kemajuan perekonomian suatu negara. Selain digunakan untuk memberikan kredit, bank juga bisa menempatkan dana yang berhasil dihimpun ke sektor investasi seperti surat berharga terlebih surat berharga yang memiliki jangka waktu yang relatif pendek. Bank bisa menginvestasikan dana ke dalam Surat Berharga Pasar Uang (SBPU) atau Interbank Call Money dengan mengharapkan bunga yang akan menjadi sumber pendapatan bagi bank.

\subsection{Pengertian Nasabah / Customer (Pelanggan)}

Menurut Prof. Dr. Sofjan Assauri, (2013) dalam bukunya " Manajemen Pemasaran Bank" yang dikutip dari "Kamus Perbankan" menyatakan bahwa "Nasabah adalah orang atau badan yang mempunyai rekening simpanan atau pinjaman pada bank".

Dari pengertian di atas penulis memberikan kesimpulan bahwa "Nasabah adalah seseorang ataupun badan usaha (korporasi) yang mempunyai rekening simpanan dan pinjaman dan melakukan transaksi simpanan dan pinjaman tersebut pada sebuah bank".

Pelanggan adalah seseorang yang membina hubungan baik dengan orang lain khususnya produsen dalam bidang usaha.Pada dasarnya ada dua jenis pelanggan, yaitu pelanggan eksternal dan pelanggan internal.

Pelanggan eksternal adalah: orang yang diluar industry yang menerima suatu produk (end user). Pelanggan eksternal setiap industri jelas adalah masyarakat umum yang menerima produk industri tersebut. Beberapa hal yang diperlukan pelanggan ekternal adalah :

a. Kesesuaian dengan kebutuhan akan produk

b. Harga yang kompetitif

c. Kualitas dan reabilitas

d. Pengiriman yang tepat waktu

e. Pelayanan purna jual

Pelanggan internal adalah: yang melakukan proses selanjutnya dari suatu pekerjaan (next proses) pelanggan internal merupakan seluruh karyawan dari suatu industry. Yang diperlukan pelanggan internal adalah:

f. Kerja kelompok dan kerjasama

g. Struktur dan sistem yang efisien

h. Pekerjaan yang berkualitas 
i. Pengiriman yang tepat waktu

\subsection{Strategi Penghimpunan}

Strategi adalah pendekatan secara keseluruhan yang berkaitan dengan pelaksanaan gagasan, perencanaan, dan eksekusi sebuah aktivitas dalam kurun waktu tertentu.

Pengertian strategi menurut Fred R David (2013) :

"Strategi adalah bakal tindakan yang menurut keputusan manajemen puncak dan strategi juga mempengaruhi kehidupan organisasi dalam jangka panjang, paling tidak selama 5 tahun. Oleh karena itu sifat strategi adalah berorientasi ke masa depan."

Pengertian strategi Menurut kasmir (2012) :

"Strategi penghimpunan adalah pelaksanaan gagasan dan perencanaan untuk memperoleh sumber dana yang berasal dari masyarakat dalam bentuk dana pihak ketiga yang bertujuan untuk mengembangkan usahanya dan demi menjaga kesehatan bank, strategi yang bisa digunakan adalah strategi pemasaran dan strategi promosi yang merupakan sarana untuk memperkenalkan produk sebuah bank kepada masyarakat."

Adapun strategi-strategi yang dilakukan dalam menghimpun dana pihak ketiga, antara lain yaitu :

A. Strategi Pemasaran

Menurut Fred R David (2013) pemasaran merupakan usaha untuk memenuhi kebutuhan dan keinginan para nasabahnya terhadap produk dan jasa. Untuk mengetahui kebutuhan dan keinginan konsumen, maka setiap perbankan perlu melakukan riset pemasaran, karena dengan melakukan riset pemasaran inilah dapat diketahui keinginan dan kebutuhan konsumen yang sebenarnya. Tujuan pemasaran bank secara umum yaitu :

1. Memaksimalkan konsumsi atau dengan kata lain memudahkan dan merangsang konsumsi sehingga dapat menarik nasabah untuk membeli produk yang ditawarkan bank secara berulang-ulang.

2. Memaksimalkan kepuasan pelanggan melalui berbagai pelayanan yang diinginkan nasabah. Nasabah yang puas akan menjadi ujung tombak pemasaran selanjutnya, karena kepuasan ini akan ditularkan kepada nasabah lainnya melalui cerita (word of mouth). 
3. Memaksimalkan pilihan (ragam produk) dalam arti bank menyediakan berbagai jenis produk bank sehingga nasabah memiliki beragam pilihan pula.

4. Memaksimalkan mutu hidup dengan memberikan berbagai kemudahan kepada nasabah dan menciptakan iklim yang efisien.

Adapun macam-macam strategi pemasaran yaitu :

1. Strategi produk

Produk bank dapat dibedakan atas dasar penggolongan sebagai berikut : Penggolongan produk berdasarkan pelayanannya, Penggolongan produk berdasarkan jenis konsumen, seperti pedagangan besar, perdagangan kecil, eksportir, lembaga keuangan dan bank lain, perorangan, dan lainlain. Penggolongan produk berdasarkan pola pembelian, misalnya dalam pelayanan simpanan giro, cara pengambilan bisa secara tunai, cek, ataupun bilyet giro. Adapun strategi produk yang dilakukan bank untuk mengembangkan suatu produk dengan cara :

a. Penentuan logo dan motto

Logo merupakan ciri khas suatu bank sedangkan motto merupakan serangkaian kata-kata yang berisikan misi dan visi bank dalam melayani masyarakat. Baik logo maupun motto harus dirancang dengan benar.

b. Menciptakan merek

Untuk berbagai jenis jasa bank ada yang perlu dberikan merek tertentu. Merek merupakan sesuatu untuk mengenal barang atau jasa yang ditawarkan

c. Menciptakan kemasan

Kemasan merupakan pembungkus suatu produk. Dalam dunia perbankan kemasan lebih diartikan kepada pemberian pelayanan atau jasa kepada para nasabah di samping juga berbagai pembungkus untuk beberapa jenis jasanya.

d. Keputusan label

Label merupakan suatu yang dilengketkan pada produk yang ditawarkan dan merupakan bagian dari kemasan. 


\section{Strategi harga}

Produk bank bisa dibedakan antara lain Produk pada sisi pasiva dari neraca bank, seperti giro, tabungan, deposito (simpanan masyarakat). Produk pada sisi aktiva dari neraca bank, seperti kredit. Harga produk bank pada sisi pasiva (simpanan masyarakat sebagai nasabah) diusahakan serendah-rendahnya (murah), sedangkan pada sisi aktiva (kredit yang diberikan kepada debitur kredit) diusahakan tinggi agar terhindar terjadinya negatif spread. Penetapan strategi harga bagi produk perbankan ditentukan antara lain oleh cost of loanable funds yang diperhitungkan serendah mungkin. Tingkat suku bunga SBI serta ketentuan Bank Indonesia yang berlaku3.Tingkat harga yang "dipasang" oleh pesaing. Profit margin (spread) yang layak. Adapun strategi harga yang dilakukan oleh bank misalnya :

a. Penetapan harga deposito berjangka

pada umumnya bank harus memperhatikan tingkat suku bunga SBI, yang merupakan reference bagi bank untuk menetapkan tingkat suku bunga depositonya, baik untuk jangka waktu 1 bulan, 3 bulan, ataupun 12 bulan. Di samping itu, Bank Indonesia juga menetapkan ketentuan yang melarang bank umum untuk memasang harga simpanan depositonya lebih tinggi dari $125 \%$ x tingkat suku bunga SBI. Sebaliknya jika bank, memasang harga terlalu rendah dibandingkan dengan bank-bank pesaingnya, dikhawatirkan para deposan mengalihkan dananya ke bank-bank pesaing tersebut.

3. Strategi lokasi

Pada pemasaran produk barang-barang industri (manufaktur) dikenal adanya rangkaian saluran distribusi yang merupakan jalur pemasaran bagi produk-produk yang dihasilkan dari pabrik. Selain itu, dengan diperkenalkannya direct banking dan telephone banking, nasabah memanfaatkan pelayanan perbankan tanpa harus memanfaatkan pelayanan perbankan tanpa harus mendatangi kantor-kantor cabang dari suatu bank yang dipilihnya. Adapun strategi lokasi yang dilakukan oleh bank misal : 


\section{a. Penentuan lokasi}

penentuan lokasi suatu bank adalah pertimbangan, yaitu dekat dengan kawasan industri atau pabrik, dekat dengan lokasi perkantoran, dekat dengan lokasi pasar, dekat dengan lokasi perumahan atau masyarakat serta mempertimbangkan jumlah pesaing yang ada di suatu lokasi.

b. Penetapan automated teller machine (ATM)

kini hampir semua bank yang besar telah memanfaatkan penggunaan automated teller machine (ATM) sehingga nasabah dapat melakukan berbagai transaksi, seperti pengambilan uang tunai, pembayaran rekening listrik, telepon dan lain-lain. Selain itu, dengan diperkenalkannya direct banking dan telephon banking, nasabah dapat memanfaatkan pelayanan perbankan tanpa harus mendatangi kantorkantor cabang dari suatu bank yang dipilihnya.

4. Strategi alternatif meningkatkan jumlah nasabah

Bank merupakan lembaga keuangan yang menghimpun dana dari dan untuk masyarakat. salah satu asset penting untuk mendukung perkembangan bank adalah banyaknya jumlah nasabah yang mempercayakan uangnya untuk ditabung di bank tersebut.Semakin banyak jumlah nasabah yang menabung maka jumlah dana yang bisa disalurkan juga akan semakin banyak. Semakin banyak penabung maka jumlah dana yang bisa disalurkan untuk kredit juga akan lebih banyak. Ini artinya, bank juga akan mendapatkan income dari pembayaran kredit setiap bulannya sehingga akan mendukung eksistensi bank. Itulah sebabnya, setiap bank harus membangun strategi yang tepat dan sehingga bisa menjadi strategi meningkatkan jumlah penabung yang benar-benar bagus. Umumnya masyarakat memilih untuk menabung di bank tertentu karena mereka yakin bank atau lembaga keuangan tersebut adalah lembaga yang bisa dipercaya.

Adapun strategi untuk meningkatkan jumlah nasabah yang dilakukan oleh bank dengan cara :

a. Membangun reputasi yang baik

Jangan harap anda akan mendapatkan banyak nasabah yang bersedia menabung di bank anda, jika selama ini bank yang ada selalu menyisakan masalah. Padahal hal tersebut merupakan salah satu 
patokan dari masyarakat hingga akhirnya mereka memutuskan untuk menjadi nasabah atau tidak.

b. Melakukan berbagai promosi

Promosi merupakan cara untuk memperkenalkan produk yang dimiliki oleh bank kepada masyarakat. Produk yang ditawarkan pastinya adalah produk yang berkaitan dengan produk untuk tabungan, deposito dan giro. Promosi yang dilakukan bisa dengan menyebarkan brosur, mengikuti berbagai pameran, dan lain sebagainya.

c. Memberikan iming iming hadiah

Hadiah bisa menjadi daya tarik tersendiri bagi para nasabah. Melihat hadiah yang besar, biasanya nasabah akan lebih termotivasi untuk terus meningkatkan saldonya sehingga dana yang bisa disalurkan untuk kredit juga akan lebih banyak. Usahakan untuk menyediakan hadiahnya terlebih dahulu dan pamerkan hadiah tersebut di ruang tunggu pada bank. Ingat, sebaiknya anda tidak mengeluarkan budget untuk hadiah ini diluar dari kemampuan bank. Sedangkan untuk pengundian hadiah bisa dilakukan setiap bulan, triwulan, atau mungkin per semester.

d. Tingkatkan pelayanan

Kepuasan pelayanan merupakan kepuasan tersendiri bagi para nasabah. Ketika mereka mendapatkan pelayanan yang baik di berbagai hal, pastinya calon nasabah akan merasa lebih nyaman untuk bertransaksi. Pelayanan dari setiap bank ini akan sangat dipengaruhi oleh SDM yang berkualitas sehingga sangat penting bagi lembaga untuk terus meningkatkan kualitas SDMnya.

e. Tawarkan berbagai kemudahan

Nasabah umumnya membutuhkan pelayanan yang mudah dan aman. Untuk memenuhi kebutuhan konsumen ini, bank bisa menawarkan berbagai fasilitas diantaranya adalah layanan mobile banking atau mungkin online banking. Dengan layanan ini, maka nasabah bisa melakukan berbagai transaksi untuk melakukan berbagai akses perbankan.

Strategi memang merupakan bagian yang penting dalam menentukan langkah-langkah tepat dalam mencapai sesuatu, karena 
tanpa strategi yang jelas akan menyebabkan tidak maksimalnya hasil yang dicapai oleh lembaga. Karena ini sebagai penunjang keberhasilan dalam berbagai kegiatan operasional bank.

B. Strategi promosi

Menurut kasmir (2012) strategi promosi adalah suatu rencana untuk penggunaan yang optimal atas sejumlah elemen-elemen promosi : periklanan, hubungan masyarakat, penjualan pribadi, dan promosi penjualan. Para manajer pemasaran menentukan tujuan dari strategi promosi penjualan dari sudut tujuan keseluruhan perusahaan bagi bauran pemasaran: produk, tempat, promosi dan harga. Adapun promosi yang diselenggarakan oleh bank bertujuan untuk menyampaikan informasi, membujuk nasabah sasaran, dan mengingatkan.

Jenis promosi yang bisa digunakan oleh bank adalah :

1. Periklanan (advertising)

Merupakan promosi yang dilakukan dalam bentuk tayangan atau gambar atau kata-kata yang tertuang dalam bentuk spanduk, brosur, billboard, majalah televisi atau media radio. Periklanan menjalankan tiga fungsi yaitu sebagai fungsi informasi, persuasif dan sebagai pengingat. Sebagai informasi ia mengkomunikasikan informasi produk, cirri-ciri dan lokasi penjualannya. Sebagai persuasif yaitu mencoba membujuk para konsumen untuk membeli merek-merek tertentu atau mengubah sikap mereka terhadap produk atau perusahaan tertentu. Sebagai pengingat yang terus mengingatkan konsumen tentang sebuah produk sehingga mereka akan tetap membeli produk yang di iklankan

2. Penjualan (sales)

Merupakan promosi yang digunakan untuk meningkatkan penjualan melalui potongan harga atau hadiah pada waktu tertentu terhadap barang-barang tertentu pula. Tujuan promosi adalah untuk meningkatkan penjualan untuk meningkatkan jumlah nasabah. Promosi penjualan dilakukan untuk menarik nasabah untuk segera membeli setiap produk atau jasa yang ditawarkan. 


\section{Publisitas (publicity)}

Merupakan promosi yang dilakukan untuk meningkatkan citra bank di depan para calon nasabah atau nasabahnya melalui kegiatan sponsorhip suatu kegiatan amal,kegiatan sosial atau olahraga. Tujuan dari promosi sendiri adalah menginformasikan, mempengaruhi, dan membujuk serta mengingatkan pelanggan sasaran tentang perusahaan dan bauran pemasarannya. Dari uraian diatas dapat diterangkan sebagai berikut yaitu :

1. Menginformasikan dapat berupa :

a. Menginformasikan pasar mengenai produk baru.

b. Memperkenalkan cara pemakaian yang baru dari suatu produk.

C. Menyampaikan perubahan harga kepada pasar.

d. Menjelaskan cara kerja produk.

e. Menginformasikan jasa-jasa yang disediakan.

2. Membujuk pelanggan sasaran untuk :

a. Membentuk pilihan merk.

b. Mengalihkan pilihan ke merk lain.

c. Mengubah persepsi pelanggan terhadap atribut produk.

d. Mendorong pembeli untuk belanja saat itu juga.

e. Mendorong pembeli untuk menerima kunjungan marketing.

3. Mengingatkan terdiri atas:

a. Mengingatkan pembeli bahwa produk yang bersangkutan dibutuhkan dalam waktu dekat.

b. Mengingatkan pembeli akan tempat-tempat yang menjual produk perusahaan.

c. Membuat pelanggan tetap ingat akan produk tanpa harus ada nya kampanye iklan.

d. Menjaga agar ingatan pertama pembeli jatuh pada produk suatu perusahaan tersebut.

4. Penjualan pribadi (Personal selling)

Dalam dunia perbankan penjualan pribadi secara umum dilakukan oleh seluruh pegawai bank, mulai dari cleaning service, satpam sampai pejabat bank. Secara khusus personal selling dilakukan oleh customer service. Setiap bank selalu ingin dianggap yang 
terbaik dimata nasabahnya. Nasabah intinya ingin diberikan pelayanan yang terbaik. Karena sekalipun pelayanan yang diberikan sudah maksimal, terkadang masih saja nasabah tidak puas sehingga pada akhirnya malah kabur ke bank saingan kita.

\subsection{Sumber Dana-Dana Bank}

Sumber dana bank berasal dari dana intern maupun ekstern sesuai dengan bidang usaha yang dijalankan bank sebagai lembaga keuangan yang kegiatan nya adalah menghimpun dana dan kemudian menyalurkan dana tersebut kepada yang membutuhkan dana tersebut. Dalam praktek kadang dijumpai ada suatu cabang bank yang merupakan sumber dana artinya dana yang dimiliki jumlahnya besar, tetapi pemberian fasilitas kreditnya relatif rendah. Untuk itu maka kantor pusat sebagai pengelola dana bank akan mengambil dana tersebut dengan memberikan keuntungan sejumlah persen tertentu atas pinjaman dana tersebut.

Kebijakan perbankan dalam mengelola dananya harus selaras dengan penggunaannya, hal ini disebabkan dana yang telah berhasil dihimpun itu akan menimbulkan biaya atau yang biasa dinamakan biaya dana atau cost of money.

Adapun sumber dana pada suatu bank antara lain sebagai berikut:

1. Dana dari modal sendiri

Dana dari modal sendiri merupakan dana yang berasal dari pemilik bank atau pemegang saham, baik pemegang saham pendiri maupun para pemegang saham yang ikut dalam usaha bank dikemudian hari dan cadangan-cadangan yang dibentuk dari laba setelah pajak.

Modal bank terdiri dari :

a. Modal inti

Dana yang telah disetor secara efektif oleh para pemegang saham yang terdiri dari saham biasa dan saham preferen.

b. Modal pelengkap

Modal pelengkap adalah cadangan-cadangan yang dibentuk oleh bank, tetapi bukan berasal dari penyisihan laba bersih dan pinajaman yang sifatnya dapat dipersamakan dengan modal. 
2. Dana dari pinjaman

Dana dari pinjaman adalah pinjaman yang diterima dari bank atau pihak lain dalam rupiah maupun dalam mata uang asing yang harus dibayar jika telah jatuh temponya.

a. Interbank Call Money Market

Pinjaman dari bank lain dengan jangka waktu yang sangat pendek yaitu dari satu hari sampai 7 hari.

b. Pinjaman antar bank

Pinjaman jangka pendek atau jangka menengah yang berasal dari bank lain dengan tingkat bunga yang relatif rendah.

c. Kredit Likuiditas Bank Indonesia (KLBI)

Pinjaman yang diterima dari bank Indonesia untuk membiayai usaha usaha masyarakat yang tergolong berprioritas tinggi.

d. Pinjaman dari Luar Negeri

Pinjaman yang diterima dari bank-bank luar negeri dengan dikenakan suku bunga tertentu yang harus dilunasi setelah jangka waktunya berakhir.

3. Sumber dana lainnya

Sumber dana yang jangka waktunya mengendapnya tidak lama namun dapat dimanfaatkan oleh bank dalam operasionalnya sumber dana yang dimaksud yaitu :

a. Setoran jaminan

Dana setoran yang berasal dari jasa-jasa bank yang diberikan atas sesuatu fasilitas yang dinikmati oleh nasabah.

b. Payment point

Fasilitas pelayanan bank untuk menerima pembayaran untuk menerima pembayaran dari perusahaan atau instansi tertentu.

c. Transfer uang

Jasa pengiriman uang dari bank untuk memindahkan dana atau uang sejumlah tertentu kepada yang ditunjuk sebagai penerima transfer.

d. Setoran pembayaran pajak

Bank menerima jasa pembayaran pajak seperti pajak badan usaha atau pajak bumi dan bangunan. 
4. Surat berharga yang diterbitkan

Surat-surat berharga jangka pendek yang dapat diperjual-belikan secara diskonto dengan bank Indonesia atau lembaga keuangan yang telah ditunjuk oleh BI

a. SBPU (Surat berharga pasar uang)

Surat pengakuan hutang yang telah diterbitkan dan di tanda tangani oleh nasabahnya yang belum mampu melunasi hutangnya sebagai jaminan atas pelunasan hutang nasabah yang bersangkutan.

b. Obligasi

Surat berharga jangka panjang yang dikeluarkan oleh bank dan merupakan sumber dana karena sebagai hutang jangka panjang.

c. Traveller's cheques (TC)

Warkat berharga atas nama yang diterbitkan oleh bank dalam valuta rupiah atau dalam valuta asing dan pencairannya dapat dilakukan kapan saja oleh orang yang memiliki dan namanya tercantum diatas TC tersebut.

\subsection{Dana Pihak Ketiga}

Dana pihak ketiga atau biasa disebut dengan dana dari deposan adalah dana yang berasal dari masyarakat luas yang jumlahnya tidak terbatas sesuai dengan kemampuan dari bank menyerap sumber dana ini. Dana yang berasal dari sumber ini paling banyak jumlahya di bank, karena pencariannya lebih mudah jika dibandingkan dengan sumber dana lainnya namun demikian biaya operasional untuk mencari sumber dana ini juga cukup mahal.

Dana pihak ketiga adalah dana dana yang berasal dari masyarakat baik perorangan maupun badan usaha yang diperoleh bank dengan menggunakan berbagai instrumen produk simpanan yang dimiliki oleh bank.

Pengertian dana pihak ketiga menurut Kasmir (2012) :

"Dana pihak ketiga adalah sumber dana dari masyarakat berupa giro, tabungan dan deposito berjangka yang berasal dari nasabah perorangan atau badan."

Dana pihak ketiga dipengaruhi biaya overhead yang berarti biaya-biaya di luar bunga contoh: souvenir, dan tingkat bunga pasar. Giro dan tabungan dipengaruhi oleh biaya overhead dari pada ratio bunga, deposito dipengaruhi 
tingkat suku bunga dari pada overhead, giro dan tabungan tergolong dana yang murah tergantung biaya overhead yang dikeluarkan, deposito tergolong dana yang mahal karena tingkat suku bunganya diatas giro dan tabungan namun overhead nya costnya relatif rendah dan dana yang murah adalah modal sendiri.

Adapun sumber dana dari deposan yang berasal dari masyarakat luas dapat dilakukan dalam bentuk:

1. Simpanan tabungan

2. Simpanan giro

3. Simpanan deposito

4. Simpanan sertifikat deposito

\subsection{Giro (Demand Deposit)}

Giro atau biasa disebut dengan rekening giro merupakan dana yang berasal dari masyarakat, perusahaan atau instasi pemerintah yang disimpan oleh nasabah ke bank serta penarikan dan penyetorannya dapat dilakukan sewaktuwaktu dan berkali-kali. Bagi bank devisa, rekening giro disamping dalam valuta rupiah dapat pula diterbitkan dalam valuta asing, misalkan dengan menggunakan valuta dollar atau USD.

A. Giro Rupiah

Pengertian giro menurut pasal 1 ayat 6 NO.7 tahun 1992 tentang perbankan sebagaimana telah diubah dengan UU No.10 tahun 1998 :

Giro adalah simpanan yang penarikannya dapat dilakukan setiap saat dengan menggunakan cek, bilyet giro, sarana perintah pembayaran lainnya, atau dengan pemindah bukuan.

Penarikan uang dari rekening giro hanya dapat dilakukan dengan perintah tertulis dari pemilik dab biasanya dengan cara menggunakan cek, bilyet giro, pemindah bukuan, penarikan kliring keluar dengan slip penarikan tunai. Sedangkan penyetorannya seperti produk simpanan bank lainnya dapat dilakukan oleh siapa saja.

Penarikan dana dari rekening giro :

1. Cek

Cek merupakan surat berharga yang dikeluarkan oleh bank yang dapat dipergunakan oleh pemegang rekening dan orang lain atau nama yang tersebut di dalam cek. 
Pengertian cek adalah surat perintah bayar tanpa syarat dari penerbit kepada bank untuk membayar sejumlah uang tertentu kepada pembawa atau nama yang tersebut di dalam cek pada saat waktu warkat ditunjukkan.

Kewajiban pihak bank sebagai pemelihara rekening giro nasabahnya adalah :

a. Melakukan pembayaran sepanjang saldonya mencukupi atau ada dananya

b. Walaupun tanggal yang tertera dalam cek belum jatuh waktu, cek tersebut tetap dapat diuangkan ke bank

c. Memberikan buku cek dan bilyet giro bila nasabah memerlukan

d. Memberikan informasi saldo akhir dari rekening giro kalau ditanya oleh nasabah

e. Melakukan transaksi kliring jika diperlukan nasabah

Jenis-jenis cek :

Adapun jenis cek yang sering dijumpai dala praktek sehari-hari di bank antara lain sebagai berikut :

a. Cek silang (cross cheque)

Adalah cek yang diberikan garis menyilang dua pada ujung kiri atas cek. Pada jenis cek ini pembayaran tidak dapat dilakukan dengan tunai melainkan dengan pemindah bukuan.

b. Cek mundur

Adalah cek yang diberikan dengan tanggal mundur terhitung dari semenjak tanggal diterbitkan. Biasanya ini terjadi karena adanya kesepakatan antara penerbit cek dengan yang, menerima cek. Misalkan: tanggal pengeluaran 10 juni 2007 dan yang ditulis dalam cek tanggal 25 juni 2007.

c. Cek kosong

Adalah cek yang pada saat digunakan tidak ada dananya sehingga tidak dapat dibayar. Ketentuan dari bank Indonesia cek kosong ini tidak boleh sampai 3 kali berturut-turut dalam tempo 6 bulan dan apabila sampai tiga kali dalam tempo 6 bulan dapat berakibat rekening pembuka cek kosong ditutup oleh bank dan selanjutnya masuk ke dalam daftar hitam bank Indonesia. 


\section{d. Cek atas nama}

Adalah cek yang diterbitkan dengan menyebutkan nama penerima di dalam cek, baik atas nama perorangan atau lembaga/perusahaan misalnya: Tn. Abdulah atau PT. Harapan Jaya.

e. Cek atas tunjuk

Adalah cek yang dikeluarkan tanpa menyebutkan nama orang atau badan usaha si penerima uang di dalam cek, pada jenis cek ini bank tetap dapat melakukan pembayaran kepada si pembawa cek tersebut.

2. Bilyet giro

Bilyet giro adalah surat berharga yang dikeluarkan oleh bank sebagai media pemindah bukuan dana dari pemilik rekening suatu bank ke rekening nasabah bank lain.

Bilyet giro adalah surat perintah dari nasabah (pemilik rekening giro) kepada bank untuk memindah bukukan sejumlah dana dari rekeningnya kepada pihak yang tercantum di dalam bilyet giro pada tanggal tertentu.

Pihak yang tercantum di dalam bilyet giro adalah penerima dana yang dipindah bukukan yang merupakan nasabah bank lain atau pada bank yang sama seperti ysng disebutkan di dalam bilyet gironya.

3. Slip pemindah bukuan

Alat untuk penarikan dana selain dengan cek atau bilyet giro adalah dengan slip pemindah bukuan. Jenis transaksi ini hany berlaku untuk transaksi nontunai, biasanya semua bank telah menyediakan slip ini di tempat front office atau customer service di dekat teller.

4. Slip penarikan tunai

Media penarikan dan penyetoran lainnya adalah slip penarikan atau penyetoran yang dipergunakan untuk jenis transaksi tunai dan slip ini biasanya sudah tersedia di kantor-kantor cabang bank

5. Kartu ATM, kartu debit

Alat lainnya untuk jenis transaksi tunai maupun non tunai yang kini hampir semua bank yang beroperasi memilikinya adalah dengan kartu ATM. Sedangkan untuk pendebetan atau sistem pembayaran dengan menggunakan kartu adalah debit card. 
Bank card adalah kartu plastik yang dikeluarkan oleh bank untuk kepentingan nasabahnya guna melakukan transaksi tunai maupun non tunai sesuai dengan kebutuhan nasabahnya.

6. Dan alat lainnya

Sejalan dengan perkembangan perbankan dalam sistem perbankan on line dengan sarana computer, maka transaksi perbankan sekarang sudah dapat dilakukan dengan media handphone yaitu disebut dengan sms banking atau dengan computer (laptop) internet banking yang langsung dilakukan oleh nasabah bank.

Dengan media ini jenis transaksi perbankan yang dapat dilakukan antara lain:

a. Pembayaran: PLN, PAM, Kartu kredit, PBB, asuransi, uang kuliah dll.

b. Transfer: antar bank, kliring

c. Intern bank: informasi saldo rekening, mutasi rekening, pembukaan deposito, dll.

B. Giro Valuta Asing

Simpanan giro selain dalam valuta rupiah dapat juga diterbitkan dalam valuta asing, misalkan dalam USD. Namun rekening giro dalam valuta asing ini hanya berlaku bagi bank devisa.Pemegang rekening giro valuta asing ini tidak diberikan cek atau bilyet giro untuk penarikan dari rekening giro valuta asingnya dan simpanan gironya yang diterbitkan dalam valuta asing misalkan dalam USD, jasa gironya juga dalam US, dollar.

Sesuai dengan ketentuan bank Indonesia maka apabila nasabah dalam menyetor atau menarik dananya dalam valuta rupiah, maka akan terjadi jual beli valuta asing sesuai dengan kurs jual beli (kurs devisa umum) yang berlaku saat itu jadi penarikan tunai dalam valuta asing apalagi dalam jumlah yang besar tidak dibenarkan.

Pemilik rekening giro valuta asing biasanya juga memiliki rekening giro rupiah sehingga memudahkan untuk transaksi pendebetan atau pengkreditannya bisa langsung dari rekening giro rupiahnya.

C. Bunga Atau Jasa Giro

Rekening giro merupakan hutang bank kepada nasabahnya sesuai dengan fungsinya sebagai rekening simpanan, maka kepada pemilik rekening giro akan mendapatkan bunga simpanan atau yang umun dinamakan jasa 
giro. Besarnya jasa giro dan cara perhitungannya antara satu bank dengan bank yang lain berbeda-beda karena sifatnya rekening giro adalah rekening Koran $(R / K)$ artinya saldonya berfluktuasi sesuai dengan transaksi yang ada dan lamanya mengendap tidak dapat dipastikan, maka bank dalam memberikan suku bunganya relatif dapat dikatakan paling rendah diantara produk simpanan bank pada umunya. Perhitungan jasa giro dapat dilakukan dengan cara :

1. Perhitungan jasa giro atas dasar saldo harian

Yaitu cara perhitungan jasa giro yang didasarkan kepada saldo tiap hari dari rekening giro nasabah.

2. Perhitungan jasa giro atas dasar saldo rata-rata

Yaitu cara perhitungan jasa giro yang didasarkan kepada penjumlahan dari saldo-saldo per tanggal tertentu dari transaksi yang ada di rekening giro, dibagi dengan jumlah per tanggal transaksinya.

3. Perhitungan jasa giro atas dasar saldo terendah

Yaitu cara perhitungan jasa giro yang didasarkan kepada saldo yang terendah pada bulan tersebut yang ada di rekening giro nasabah.

\subsection{Tabungan (Saving)}

Mintardjo ( 2013 : 17 ) pengertian tabungan adalah :

Simpanan pihak ketiga pada bank yang penarikannya hanya dapat dilakukan dengan syarat - syarat tertentu dan tidak dapat ditarik dengan cek atau yang dipersamakan dengan itu.

Menurut UU Perbankan :

Tabungan adalah simpanan yang penarikannya hanya dapat dilakukan menurut syarat tertentu yang disepakati, tetapi tidak dapat ditarik dengan cek, bilyet giro, dan atau alat lainnya yang dipersamakan dengan itu.

Mia Lasmi ( 2013 : 161 ) pun menyatakan bahwa tabungan adalah :

Simpanan yang penarikannya hanya dapat dilakukan dengan syarat tertentu yang disepakati, dan tidak dengan cek atau bilyet giro atau alat lain yang dapat dipersamakan dengan itu.

Dari beberapa pengertian diatas tabungan adalah simpanan pihak ketiga pada bank yang penarikannya hanya dapat dilakukan menurut syarat tertentu 
antara bank dan nasalah. Tabungan tidak dapat ditarik dengan menggunakan cek, bilyet giro, atau alat lainnya yang dipersamakan dengan itu.

Produk perbankan ini memiliki kelebihan dibanding produk lainnya. Tabungan dapat dibuka dengan sejumlah uang yang relatif terjangkau oleh semua kalangan masyarakat. Penyetoran dana untuk produk tabungan dapat dilakukan dengan mudah. Nasabah bisa melakukan setoran langsung ke bank menggunakan formulir penyetoran. Nasabah juga bisa melakukan pemindahbukuan dan transfer rekening dengan menggunakan formulir transfer atau mesin ATM. Bahkan sekarang nasabah bisa melakukan setoran tunai melalui mesin CDM. Cara penarikannya pun relatif mudah hanya dengan menggunakan buku tabungan dan kartu ATM. Persaingan yang ketat dalam penghimpunan dana melalui tabungan membuat bank memunculkan cara baru untuk menarik nasabah tabungan antara lain hadiah atas tabungan tersebut, asuransi, fasilitas kartu ATM dan fasilitas kartu debet.

Sektor perbankan banyak memperebutkan produk tabungan dengan mekanisme pemberian hadiah yang besar - besar. Hal ini dilakukan karena pangsa tabungan dapat menjangkau semua lapisan masyarakat sehingga memperebutkan pangsa pasar tabungan bukanlah suatu pekerjaan yang sia - sia bagi bank.

Bank memberikan bunga untuk imbalan atas saldo yang mengendap di rekening tabungan. Bunga yang diberikan oleh bank terhadap produk tabungan berada di tengah - tengah antara bunga yang diberikan terhadap produk giro maupun deposito berjangka. Ditinjau dari sisi bank, penghimpunan dana melalui tabungan termasuk lebih murah daripada deposito, tetapi lebih mahal dibandingkan giro. Seperti yang telah dijelaskan diatas, pangsa pasar dari simpanan tabungan tak terbatas, namun masyarakat sekarang sudah pandai memilih sehingga simpanan tabungan biasanya terdapat undian dengan hadiahhadiah menarik. Dalam praktek perbanjan umumnya bunga tabungan dihitung atas dasar saldo harian dan sesuai dengan ketentuan pemerintah, maka bunga tabungan dikenakan pajak seperti produk simpanan lainnya.

Adapun manfaat tabungan bagi nasabah antara lain sebagai berikut :

1. Mendapatkan bunga atas uang yang disimpan di bank.

2. Dapat melakukan penarikan maupun setoran tunai di bank.

3. Transaksi non-tunai dengan pemindah bukuan, kliring, dan transfer. 
4. Dengan fasilitas ATM, SMS Banking, atau internet Banking dapat melakukan penarikan tunai di ATM dengan cara seperti cek saldo rekening, transfer antar rekening dalam satu bank, transfer antar rekening dilain bank dengan media ATM berlogo link atau ATM bersama, pembayaran tagihan telepon atau listrik, pembayaran kartu kredit, pembelian tiket, pembayaran uang kuliah, dan sebagainya.

Sejalan dengan pengembangan produk dan dalam rangka penyerapan dana yang lebih optimal dari masyarakat maupun perusahaan maka bankbank devisa kini telah mulai mengeluarkan produk simpanan tabungan dalam valuta asing dengan berbagai jenis valutanya.

Pada umumnya tabungan dalam valuta asing dibuka dengan mata uang yang kuat di pasaran seperti USD, SGD, AUD, dan HKD.

Untuk penyetoran maupun penarikan dapat dilakukan dalam valuta asing dengan jenis valuta yang sama, sehingga menghemat biaya provisi dan selisih kurs jual beli bank namun dengan batasan tertentu seperti jumlah minimal penarikan setoran dengan kelipatan jumlah uang tertentu dan tentunya dalam kondisi yang baik menurut kriteria bank.

\subsection{Deposito (Time Deposit)}

Deposito Berjangka

Mia Lasmi ( 2013 : 160 ) mengatakan bahwa pengertian deposito berjangka adalah : "Simpanan yang penarikannya hanya dapat dilakukan pada waktu tertentu sesuai tanggal yang dijanjikan deposan dan bank." Selain itu, menurut Mintardjo ( 2013 : 10 ) pengertian deposito berjangka adalah : "Simpanan pihak ketiga pada bank yang penarikannya hanya dapat dilakukan dalam jangka waktu tertentu menurut perjanjian antara pihak ketiga dan bank bersangkutan".

Pengertian simpanan deposito menurut pasal 1 ayat 7 UU No.10 tahun 1998 tentang perbankan: deposito adalah simpanan yang penarikannya hanya dapat dilakukan pada waktu tertentu berdasarkan perjanjian nasabah penyimpan dengan pihak bank.

Kedua penulis diatas mengatakan bahwa deposito berjangka adalah simpanan masyarakat atau pihak ketiga yang penarikannya hanya bisa dilakukan pada saat jatuh tempo sesuai dengan tanggal perjanjian antara nasabah dengan 
bank pada saat penempatan. Jangka waktu deposito berjangka di Indonesia pada umumnya 1, 3, 6, dan 12 bulan. Maksimal penempatan deposito berjangka adalah dua tahun. Minimal penempatan untuk deposito berjangka tergantung dari masing - masing bank. Pada umumnya bank menetapkan minimal penempatan deposito sebesar 8 juta rupiah.

Deposito berjangka hanya dapat dicairkan pada saat jatuh tempo oleh pihak yang namanya tercantum dalam bilyet deposito sesuai tanggal jatuh temponya. Deposito berjangka merupakan simpanan atas nama bukan atas unjuk.

Deposito berjangka memiliki kelebihan dapat ditarik tunai setiap jangka waktu tertentu dan atau bisa ditransfer ke suatu rekening deposan. Nasabah biasanya juga membuka rekening tabungan untuk menampung bunga atas deposito tersebut dan untuk menampung dana deposito yang sudah jatuh tempo. Bank juga memberikan fasilitas agar bunga deposito yang tidak ditarik dapat ditambahkan dalam simpanan pokok deposito sehingga nilai deposito berjangkanya bertambah besar. Pada dasarnya, sebelum jatuh tempo simpanan ini tidak dapat ditarik dan biasanya bank mengenakan denda atau biaya administrasi jika simpanan tersebut ditarik sebelum jatuh tempo. Namun dengan persaingan perbankan saat ini, banyak bank yang tidak mengenakan denda ke nasabah jika nasabah ingin mencairkan deposito berjangkanya sebelum jatuh tempo.

Kelebihan dana deposito bagi bank adalah adanya kepastian tentang penarikan dana sehingga pihak bank dapat mengantisipasi untuk menyediakan dana dalam jumlah tertentu. Sebagai konsekuensinya, bank harus membayar dengan tingkat bunga yang relatif lebih tinggi dibandingkan produk yang lainnya. Dengan kata lain, simpanan deposito berjangka merupanan sumber penghimpunan dana mahal bagi bank.

Dilihat dari sisi deposan atau nasabah mereka cenderung menyukai untuk menyimpan kelebihan dananya dalam bentuk deposito berjangka sesuai dengan jangka waktu yang diinginkan karena simpanan ini menawarkan tingkat bunga yang relatif tinggi. Bank juga akan bersaing dalam memberikan bunga yang tinggi namun tidak boleh melebihi ketentuan dari Lembaga Penjamin Simpanan. Nasabah bisa memilih bank mana yang memberikan bunga tinggi untuk produk depositonya. 
Jadi simpanan deposito atau lebih dikenal dengan deposito berjangka adalah simpanan masyarakat atau perusahaan yang pencairannya dapat dilakukan setelah jangka waktu yang telah disetujui berakhir. Walaupun jangka waktu deposito telah disetujui oleh nasabah dan pihak bank namun apabila nasabah yang memiliki deposito menghendaki pencairan sebelum jangka waktu yang telah ditetapkan oleh kesepakatan diantara dua pihak biasanya akan dikenakan penalty yang berarti tidaka akan mendapatkan bunga yang berjalan samapai dengan tanggal pencairannya. Dalam memberikan sanksi berupa penalty kepada nasabahnya masing-masing bank tidak sama namu biasanya tetap ada apapun bentuk aplikasinya karena agar nasabah tidak seenaknya menarik simpanannya.

\section{a. Bunga Deposito}

Karena simpanan deposito merupakan hutang bank, maka kepada deposan diberikan bunga sebagai jasa. Besarnya suku bunga antara bank yang satu dengan lainnya berlainan, tergantung kepada manajemen dari masingmasing bank tersebut.

b. Deposito Berjangka Valuta Asing (VA)

Simpanan deposito ini dapat diterbitkan dalam valuta asing, misalkan dalam USD. Untuk itu nasabah apabila menyetornya dengan uang tunai maka harus membeli sejumlah valuta asing yang dikehendaki sesuai dengan kurs jualbeli yang berlaku saat ini.

Biasanya nasabah pemilik deposito valuta asing (VA) juga memiliki rekening giro rupiah atau rekening tabungan sehingga untuk transaksi pendebetan atau pengkreditannya bisa langsung dari rekenig giro rupiahnya seperti sewaktu penerbitan deposito valuta asing atau sewaktu pencairan deposito yang telah jatuh tempo dan penerimaan bunganya.

c. Sertifikat Deposito

Salah satu pengembangan dari produk deposito oleh pihak perbankan dalam rangka menarik dana masyarakat adalah sertifikat deposito. Sama halnya dengan deposito berjangka sertifikat deposito juga diterbitkan dalam jangka waktu 1 bulan, 3 bulan, 6 bulan, 9 bulan, atau 1 tahun bahkan lebih tergantung kesepakatan antara pihak nasabah dengan pihak bank dan juga memiliki no seri yang berurutan seperti deposito.

Perbedaan nya antara lain terletak pada sebagai berikut : 
a. Pembayaran bunga, dimana bunga sertifikat deposito dapat diambil di muka

b. Sertifikat deposito diterbitkan atas tunjuk, dengan sendirinya dapat diperjual belikan atau dipindah tangankan kepada orang lain apabila jangka waktunya belum berakhir

c. Penerbitan sertifikat deposito biasanya sudah tercetak dengan berbagai nilai nominal dengan jumlah bulat

d. Nama pemilik tidak tercantum pada sertifikat depositonya

e. Deposit On Call

Produk deposito lainnya yang belum diketahui atau jarang diketahui oleh masyarakat umum adalah deposit on call (DOC). Hal ini disebabkan deposit on call hanya memiliki jangka waktu yang relatif cukup pendek, yaitu minimal 7 hari dan paling lama hanya 1 bulan, disamping itu nilai DOC biasanya ditentukan dalam jumlah yang besar. Apabila nasabah ingin menerbitkan deposito namun dalam nilai/jumlah yang kecil biasanya pihak bank akan menawarkan produk deposito berjangka biasa.

Penerbitan DOC biasanya dilakukan oleh perusahaan-perusahaan atau antar bank yang memiliki kelebihan dana namun dalam jangka waktu yang pendek. Karena jumlahnya relatif besar dan jangka waktunya termasuk singkat maka bank dalam memberikan besarnya suku bunga dapat dilakukan dengan negoisasi dan sebagai dasar perhitungan adalah bulanan. Cara perhitungan besarnya bunga DOC sama dengan cara perhitungan simpanan deposito. 


\section{BAB III \\ HASIL DAN PEMBAHASAN}

\subsection{Sejarah Bank Rakyat Indonesia (BRI)}

BRI unit Cibinong berdiri tanggal 11 Maret 1974 pada saat itu bernama Koperasi Urusan Tani (KUT). BRI unit Cibinong merupakan salah satu unit BRI cabang Cibinong yang beroperasi untuk melayani masyarakat. Bank Rakyat Indonesia (BRI) adalah salah satu bank milik pemerintah yang terbesar di Indonesia. Pada awalnya Bank Rakyat Indonesia (BRI) didirikan di Purwokerto, Jawa Tengah oleh Raden Bei Aria Wirjaatmadja dengan nama De Poerwokertosche Hulp en Spaarbank der Inlandsche Hoofden atau "Bank Bantuan dan Simpanan Milik Kaum Priyayi Purwokerto", suatu lembaga keuangan yang melayani orang-orang berkebangsaan Indonesia (pribumi). Lembaga tersebut berdiri tanggal 16 Desember 1895, yang kemudian dijadikan sebagai hari kelahiran BRI.

Pada periode setelah kemerdekaan RI, berdasarkan Peraturan Pemerintah No. 1 tahun 1946 Pasal 1 disebutkan bahwa BRI adalah sebagai Bank Pemerintah pertama di Republik Indonesia. Dalam masa perang mempertahankan kemerdekaan pada tahun 1948, kegiatan BRI sempat terhenti untuk sementara waktu dan baru mulai aktif kembali setelah perjanjian Renville pada tahun 1949 dengan berubah nama menjadi Bank Rakyat Indonesia Serikat. Pada waktu itu melalui PERPU No. 41 tahun 1960 dibentuklah Bank Koperasi Tani dan Nelayan (BKTN) yang merupakan peleburan dari BRI, Bank Tani Nelayan dan Nederlandsche Maatschappij (NHM). Kemudian berdasarkan Penetapan Presiden (Penpres) No. 9 tahun 1965, BKTN diintegrasikan ke dalam Bank Indonesia dengan nama Bank Indonesia Urusan Koperasi Tani dan Nelayan.

Setelah berjalan selama satu bulan, keluar Penpres No. 17 tahun 1965 tentang pembentukan bank tunggal dengan nama Bank Negara Indonesia. Dalam ketentuan baru itu, Bank Indonesia Urusan Koperasi, Tani dan Nelayan (eks BKTN) diintegrasikan dengan nama Bank Negara Indonesia unit II bidang Rural, sedangkan NHM menjadi Bank Negara Indonesia unit II bidang Ekspor Impor (Exim).

Berdasarkan Undang-Undang No. 14 tahun 1967 tentang Undang-undang Pokok Perbankan dan Undang-undang No. 13 tahun 1968 tentang Undang- 
undang Bank Sentral, yang intinya mengembalikan fungsi Bank Indonesia sebagai Bank Sentral dan Bank Negara Indonesia Unit II Bidang Rular dan Ekspor Impor dipisahkan masing-masing menjadi dua Bank yaitu Bank Rakyat Indonesia dan Bank Ekspor Impor Indonesia. Selanjutnya berdasarkan Undang-undang No. 21 tahun 1968 menetapkan kembali tugas-tugas pokok BRI sebagai bank umum.

Sejak 1 Agustus 1992 berdasarkan Undang-Undang Perbankan No. 7 tahun 1992 dan Peraturan Pemerintah RI No. 21 tahun 1992 status BRI berubah menjadi perseroan terbatas. Kepemilikan BRI saat itu masih $100 \%$ di tangan Pemerintah Republik Indonesia. Pada tahun 2003, Pemerintah Indonesia memutuskan untuk menjual 30\% saham bank ini, sehingga menjadi perusahaan publik dengan nama resmi PT. Bank Rakyat Indonesia (Persero) Tbk., yang masih digunakan sampai dengan saat ini.

PT. Bank Rakyat Indonesia (Persero) yang didirikan sejak tahun 1985 didasarkan pelayanan pada masyarakat kecil sampai sekarang tetap konsisten, yaitu dengan fokus pemberian fasilitas kredit kepada golongan pengusaha kecil atau Usaha Mikro kecil menengah (UNKM). Hal ini antara lain tercemin pada perkembangan penyaluran KUK pada tahun 1994 sebesar Rp. 6.419,8 milyar yang meningkat menjadi Rp. 8.231,1 milyar pada tahun 1995 dan pada tahun 1999 sampai dengan september sebesar Rp. 20,466 milyar.

Seiring dengan perkembangan dunia perbankan yang semakin pesat maka sampai saat ini Bank Rakyat Indonesia memiliki Unit kerja yang berjumlah 4.447 buah, yang terdiri dari 1 Kantor Pusat BRI, 12 Kantor Wilayah, 12 Kantor Inspeksi/SPI, 170 Kantor Cabang (Dalam Negeri), 145 Kantor Cabang Pembantu, 1 Kantor Cabang Khusus, 1 New York Agency, 1 Caymand Island Agency, 1 Perwakilan Hongkong, 40 Kantor Kas Bayar, 6 Kantor Mobil Bank, 193 P. Point, 3.705 BRI Unit dan 357 Pos Pelayanan Desa.

Kantor BRI unit Cibinong ini terletak di Jl.Raya Bogor Km 45 Cibinong dengan wilayah kerja yang cukup strategis. Lokasi kantor yang bersebrangan dengan pasar cibinong yang sering didatangi warga disana adalah sebagai salah satu pusat kegiatan usaha masyarakat cibinong dan masyarakat disana sangat mendukung salah satu produk BRI unit Cibinong yaitu penyaluran kredit bagi masyarakat kecil untuk membantu kelancaran dan kemajuan usahanya. Selain itu, masyarakat banyak yang mempercaryakan dananya dihimpun di bank BRI unit Cibinong dalam bentuk tabungan dan deposito untuk keamanan dan 
menghasilkan keuntungan. Bank BRI unit Cibinong menjadi idola dalam memberikan pelayanan jasa keuangan bagi masyarakat setempat. Hal ini dibuktikan dengan keadaan kantor BRI unit Cibinong pada setiap hari kerjanya selalu dipadati oleh masyarakat Cibinong.

\subsubsection{Visi dan Misi Bank BRI}

Visi BRI

Menjadi bank komersial terkemuka yang selalu mengutamakan kepuasan nasabah.

Misi BRI

1. Melakukan kegiatan perbankan yang terbaik dengan mengutamakan pelayanan kepada usaha mikro, kecil dan menengah untuk menunjang peningkatan ekonomi masyarakat.

2. Memberikan pelayanan prima kepada nasabah melalui jaringan kerja yang tersebar luas dan didukung oleh sumber daya manusia yang profesional dan teknologi informasi yang handal dengan melaksanakan manajemen risiko serta praktek Good Corporate Governance (GCG) yang sangat baik.

3. Memberikan keuntungan dan manfaat yang optimal kepada pihak-pihak yang berkepentingan (stakeholders).

\subsubsection{Produk-Produk Tabungan Bank BRI}

Adapun Produk-Produk Dana Pihak Ketiga pada Bank BRI unit Cibonong Bogor, adalah sebagai berikut :

1. Tabungan Simpedes (Tabungan Simpanan Pedesaan)

Merupakan pelayanan tabungan biasa yang tidak dibatasi jumlah maupun jangka waktu penarikannya dengan pemberian bunga yang bertingkat berdasarkan jumlah tabungan. Dalam Tabungan Simpedes terdapat beberapa jenis produk tabungan lainnya, yaitu sebagai berikut :

a. Simpedes TKI

Tabungan Simpedes TKI hampir memiliki kesamaan dengan Tabungan Simpedes pada umumnya yang membedakan adalah Tabungan ini dikhususkan untuk para Tenaka Kerja Indonesia.

b. Simpedes Impian

Adalah tabungan yang mampu mengakomodir kebutuhan nasabah dalam merencanakan masa depannya yang berhubungan dengan rencana investasi, pendidikan, maupun rencana lainnya yang bersifat financial. 


\section{Tabungan Britama}

Tabungan Britama adalah salah satu produk unggul pada Bank BRI. Britama adalah pelayanan tabungan biasa yang tidak dibatasi jumlah maupun jangka waktu penarikannya dengan pemberian bunga yang bertingkat berdasarkan jumlah tabungan yang dimiliki nasabah, yang membedakan dengan tabungan simpedes hanyalah pada tingkat suku bunga. Adapun jenis Tabungan Britama yang lainnya, seperti :

a. Britama Bisnis

Britama Bisnis memberikan keleluasaan lebih dalam bertransaksi, kejelasan dalam pencatatan dan keuntungan lain yang menunjang transaksi dan kebutuhan bisnis.

b. Britama Junio

Tabungan Junio merupakan tabungan anak yang secara khusus dilengkapi fasilitas dan fitur yang menarik bagi kebutuhan anak. Tabungan Junio ini terbagi menjadi dua jenis yaitu Bundling dan Non-Bundling. Untuk jenis Bundling ini diperuntukan untuk anak usia kurang dari 17 tahun dan belum memiliki identitas dan wajib memiliki rekening induk orang tua wali. Sedakangkan Non-Bundling ini jenis tabungan untuk anak yang berusia kuran dari 17 tahun namun telah memiliki identitas Kartu Pelajar dan untuk anak usia lebih dari 17 tahun.

c. Britama Valas

Tabungan mata uang asing yang menawarkan kemudahan transaksi dan nilai tukar yang kompetitif tersedia dalam lima jenis currency meliputi USD, AUD, SGD, CNY, EUR. Pembukaan rekening dapat dilakukan di kantor BRI yang terdapat diwilayah domisli KTP, untuk pembukaan diluar wilayah domisili KTP harus disertai dengan surat keterangan domisili.

d. Britama Rencana

Adalah tabungan investasi yang memberikan kebebasan perencanaan dana, perlindungan, dan kepastian untuk berbagai kebutuhan seperti dana liburan, pendidikan, perjalanan ibadah, pernikahan, hingga dana pensiun. 


\subsection{Struktur Organisasi dan Uraian Tugas}

Sebuah organisasi dalam suatu badan usaha merupakan hal yang sangat penting sebab organisasi merupakan kumpulan dari pada manusia yang terorganisir, yang mempunyai keinginan bersama dalam mencapai suatu tujuan. Guna mencapai tujuan tersebut, dibutuhkan tahapan waktu dan susunan ditata dengan baik mulai dari pembagian jabatan, pembagian tugas dan wewenang. Sebab dalam organisasi terdapat batasan tanggung jawab dari masing-masing petugas yang sesuai dengan perannya sendiri-sendiri. Sehingga dengan dibentuknya organisasi maka semua kegiatan atau aktifitas dalam suatu perusahaan dapat diatur dengan baik dan pencapaian tuhuan perusahaan semakin terarah.

BRI Unit Cibinong di pimpin oleh seorang kepala unit (Kaunit) yang membawahi mantri, Supervisor, Customer Service, dan Teller. Adapun struktur organisasi PT. Bank Rakyat Indonesia (Persero) Tbk. Unit Cibinong : 
Struktur Organisasi Bank BRI

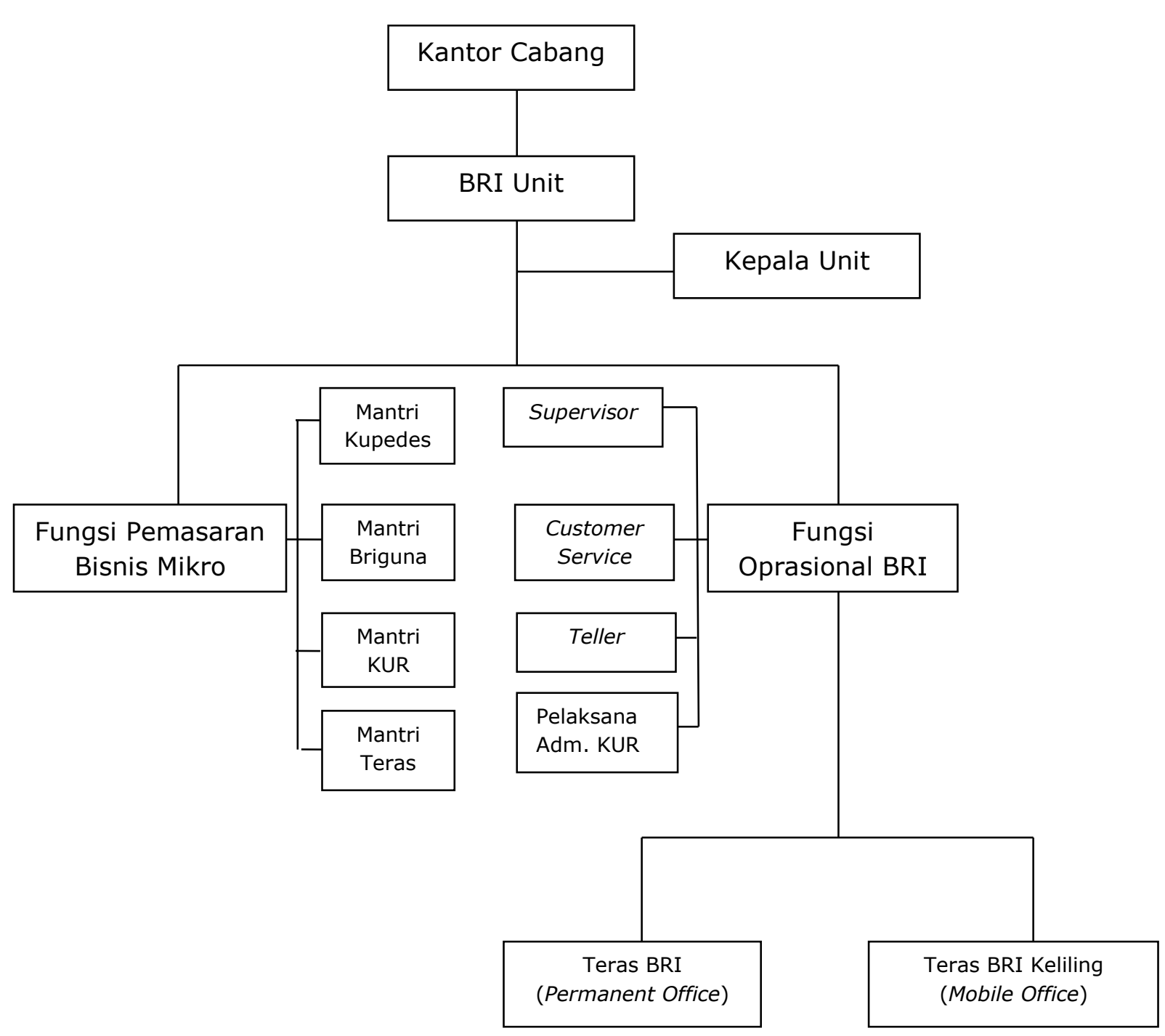

Sumber : Bank Rakyat Indonesia Persero, TBK.

Gambar 3.1

Struktur Organisasi PT. Bank Rakyat Indonesia (Persero) Tbk.

Unit Cibinong 
Uraian Tugas

1. Wewenang dan Tanggung jawab Kepala Unit

Kepala Unit bertugas bertanggung jawab atas kantor unit yang dipimpinnya. Adapun wewenang dan tanggung jawab kepala unit adalah sebagai berikut :

a. Memutuskan permintaan pinjaman sesuai kewenangannya

b. Menandatangani pencairan simpanan sesuai limit kewenangannya

c. Menandatangani surat-surat keluar biasa yang terdiri dari surat keluar rutin

d. Mengembangkan bisnis BRI unit diwilayah kerjanya untuk mencapai laba

e. Melakukan pembinaan terhadapa nasabah pinjaman dan simpanan

f. Mengadakan hubungan kerjasama dengan instansi terkait untuk meningkatkan pelayanan secara optimal

g. Memimpin kantor BRI unit dalam rangka menjamin kelancaran operasional BRI unit

h. Memonitor dan menganalisis laporan laporan BRI Unit yang meliputi laporan kekuatan pegawai, laporan temuan kasus serta lain yang dianggap penting

2. Tanggung jawab dan wewenang Supervisor

a. Mengelola Kas BRI Unit (termasuk kas ATM dan Teras BRI) sesuai dengan kewenangannya dan ketentuan yang berlaku

b. Mengelola e-channel (ATM, EDC \&e-channel lainnya) sesuai dengan kewenangannya untuk memastikan optimalisasi transaksi e-banking sesuai dengan ketentuan yang berlaku

c. Mensupervisi dan memonitoring semua rekening tabungan yang sudah bundling dengan Kartu ATM dan SMS Banking

d. Menjaga kerahasian password yang dikelola Supervisor Unit untuk memastikan tidak terjadi penyalahgunaan dalam rangka menjaga kerahasian transaksi

e. Mensupervisi fungsi Program Anti pencucian Uang (APU) dan Pencegahan Pendanaan Terorisme (PPT) secara efektif 
f. Mensupervisi dan mengevaluasi SDM di jajaran operasional termaksud dalam hal pengusulan Formasi Jabatan sesuai kewenangannya untuk memastikan pengelolaan SDM berjalan sesuai kebijakan yang berlaku

g. Mensupervisi operasional dan layanan secara efisien dan prudent dalam proses pemeriksaan, registrasi dan administrasi pinjaman, simpanan BRI Unit dan Jasa bank lainnya untuk meningkatkan kepuasan nasabah sesuai ketentuan yang berlaku.

3. Tanggung jawab dan wewenang mantri

a. Meneliti berkas-berkas kredit

b. Melakukan kegiatan Survei / on the spot ketempat usaha calon nasabah pinjaman

c. Menganalisis dan memeriksa permintaan pinjaman dan mengusulkan putusan pinjaman agar pinjaman yang diberikan layak dan aman bagi pihak-pihak bank

d. Memperkenalkan dan memasarkan produk BRI unit untuk mencapai profit yang maksimal

e. Menangani tunggakan dan mengusulkan langkah-langkah penanggulangan untuk meningkatkan kualitas pinjaman

f. Memproses dan mengusulkan permintaan pinjaman

4. Tanggung jawab dan wewenang Customer Service

a. Memberikan pelayanan kepada nasabah atau calon nasabah dengan sebaik-baiknya

b. Menyimpan berkas pinjaman dna agunan dalam rangka pengamanan asset bank

c. Menatausahakan pengarsipan bukti-bukti pembukuan dan pengelola penyimpanan berkas pinjaman dan simpanan

d. Membuat dan mengadministrasikan laporan-laporan BRI Unit

e. Mengagendakan serta merekap surat-surat masuk dan keluar dari bank BRI Unit

5. Teller

a. Menerima setiap transaksi nasabah (baik tunai maupun nontunai) serta menempatkan asset nasabah sesuai jenisnya

b. Membukakan setiap transaksi nasabah dan membuat laporan transaksi nasabah 

c. Memeriksa buku tabungan nasabah
d. Membuat laporan laba rugi

\subsection{Sumber Daya Manusia}

Organisasi BRI unit Cibinong dipimpin oleh Seorang Kepala unit yang berperan sebagai penanggung jawab keseluruhan kinerja dari BRI unit Cibinong. Dibawah Kepala Unit ada 4 (empat) orang Mantri yang bertanggung jawab atas kelancaran penyaluran dan pengembalian kredit termasuk di dalamnya melakukan pemantauan dan pembinaan kepada nasabah penerimaan kredit (debitur).

Selain mantri, ada 4 (empat) orang yang menduduki posisi Customer Service didalam kantor BRI Unit Cibinongyang dibagi menjadi dua posisi yaitu Customer Service Tabungan yang bertugas dalam melayani segala bentuk tabungan (termasuk pembukaan Rekening tabungan, deposito, dll) dan Customer Service Pinjaman yang bertugas sebagai analisis pertama dalam memeriksa kelengkapan persyaratan calon nasabah penerima pinjaman (Kredit). Bank BRI Unit Cibinong juga memiliki 2 (dua) orang Customer Service yang menduduki posisi Teras BRI Kantor dan Teras BRI Keliling. Selain itu juga ada 6 (enam) orang teller yang bertugas menangani pelayanan tabungan, penarikan tabungan dan jasa lainnya. Disamping pegawai inti tersebut BRI Unit Cibinong juga memiliki 3 (tiga) orang staf keamanan dan 2 (dua) staff pembantu. Masingmasing jenjang pendidikan para pegawai BRI Unit Cibinong tersebut adalah D3 , S1 dan SLTA yang pada umumnya telah bekerja selama kurang lebih dua tahun di BRI Unit Cibinong.

\subsection{Sarana dan Prasarana}

Dalam suatu proses tata operasi kerja pada suatu perusahaan adanya sarana dan prasarana sangat dibutuhkan dalam menunjang kelancaran sistem kerja suatu perusahaan. Sarana dan prasarana menjadi alat untuk terciptanya suatu proses kerja yang lebih mudah dan praktis jika dikelola dengan baik dan benar.

BRI Unit Cibinong terletak di Jl.Raya Bogor Km 45 Cibinong. Dengan kondisi bangunan yang baik berbentuk kantor dangan 2 lantai. Memiliki tempat parkir yang luas dan memiliki taman yang cukup luas yang berada di belakang kantor, 
serta terdapat 3 fasilitas ATM yang berada diluar bangunan kantor. Adapun tataletak bagian pelayanan transaksi perbankan berada pada lantai bawah bagian operasional. Tata unit ruangan operasional tertata dengan rapih dan bersih, sehingga kenyamanan dapat dirasakan oleh nasabah yang datang.

Bank BRI unit Cibinong memliki lokasi yang sangat strategis karena lokasi nya yang berada disebrang jalan adapun batas-batasnya :

1. Sebelah Utara Pasar Cibinong

2. Sebelah Selatan daerah Pabuaran

3. Sebelah Timur gereja

4. Sebelah Barat Bank Permata

Kelengkapan prasarana yang juga ikut andil dalam terciptanya tata operasi yang baik sehingga sangatlah penting karena dengan adanya prasarana tersebut dapat mempermudah tercapainya tujuan perusahaan dengan baik. Adapun sarana dan prasarana yang terdapat pada BRI Unit Cibinong diantaranya adalah :

Tabel 3.1

Sarana dan Prasarana Bank BRI

\begin{tabular}{|c|l|c|c|}
\hline No. & \multicolumn{1}{|c|}{ Nama Barang } & Jumlah Barang & Kualitas \\
\hline 1. & CCTV & 6 & Baik \\
\hline 2. & AC & 4 & Baik \\
\hline 3. & Telepon & 1 & Baik \\
\hline 4. & Faximile & 6 & Baik \\
\hline 5. & Mesin Printer & 1 & Baik \\
\hline 6. & Mesin Fotocopi & 4 & Baik \\
\hline 7. & Mesin Penghitung Uang & 1 & Baik \\
\hline 8. & Mesin Absen Pegawai & 16 & Baik \\
\hline 9. & Komputer (PC) & 1 & Baik \\
\hline 10. & Televisi & 1 & Baik \\
\hline 11. & Lemari Arsip & 1 & Baik \\
\hline 12. & Berangkas & 1 & Baik \\
\hline 13. & Generator & 25 & Baik \\
\hline 14. & Meja dan Kursi Pegawai & 3 & Baik \\
\hline 15. & Kursi Nasabah & 1 & Baik \\
\hline 16. & Mesin No. Antrian & & \\
\hline
\end{tabular}




\begin{tabular}{|c|l|c|c|}
\hline 17. & Speaker & 1 & Baik \\
\hline 18. & Musholla & 1 & Baik \\
\hline 19. & Mobil Teras Keliling & 1 & Baik \\
\hline 20. & Teras Pasar BRI & 1 & Baik \\
\hline
\end{tabular}

\subsection{Uraian Singkat Kegiatan Magang}

Selama melakukan Praktek Kerja Lapangan (PKL) yang berlangsung selama dua bulan terhitung sejak tanggal 09 Maret 2015 sampai dengan 08 Mei 2015 penulis ditempatkan dibagian Customer Sevice Pinjaman. Namun dalam menjalankan tugas tidak hanya menyelesaikan tugas pada bagian tersebut saja melaikan mengenal serta membantu tugas pada unit lainnya yang berada pada BRI Unit Cibinong. Adapun tugas dan kegiatan penulis adalah sebagai berikut:

1. Minggu Pertama

Mula-mula melakukan tahap pengenalan terhadap bank BRI setelah itu pembimbing memberikan pengarahan setelah melakukan pengarahan, dilanjutkan dengan mengisi Surat Keterangan Pengajuan Pinjaman (SKPP) lalu mengisi buku Register Realisasi pinjaman fungsi dari buku register realisasi adalah untuk mencatat nasabah yang pinjamannya sudah dicairkan oleh Bank BRI. Pada minggu pertama juga penulis berkesempatan untuk ikut dengan mantri melakukan survey ke 9 lokasi yang berbeda di daerah Cibinong yang mempunyai tujuan untuk melihat usaha nasabah yang tadinya sudah mengajukan pinjaman kredit di bank BRI unit Cibinong. selain itu, penulis juga $r$ berkesempatan melihat mantri secara langsung melakukan penagihan terhadap nasabah yang mengalami penunggakan dalam membayar angsuran jadi secara langsung mantri akan mendatangi rumah nasabah yang bersangkutan.

2. Minggu Kedua

Membantu mengisi Slip Setoran Tunai yang akan digunakan pada Terras Pasar, menulis buku Register Realisasi seperti biasa dalam pencairan hari teresebut , mengisi buku SKPP yang bertujuan untuk mencatat nasabah yang sudah mengajukan pinjaman ke Bank BRI unit Cibinong , dan mengisi buku Registrasi DH (Daftar Hitam) dengan mengisi buku register DH (Daftar hitam) ini bertujuan untuk mencatat nasabah yang sudah mengalami 
penunggakan angsuran yang selama tidak dibayarkan dan agunan nya akan di tahan sampai nasabah tersebut dapat melunasi angusaran nya.

3. Minggu Ketiga

Pada minggu ini penulis melakukan kegiatan yang sama pada mingguminggu sebelumnya yaitu mengisi buku SKPP dan mengisi buku Register Realisasi selain itu penulis melakukan register pangkal pinjaman nasabah karena berkas yang sudah dicairkan akan dimasukkan dalam lemari dokumen nomor pangkal ini akan memudahkan pegawai bank BRI unit Cibinong untuk mencari berkas pinjaman tersebut jika sedang dibutuhkan. Selain itu, penulis juga membuat surat pernyataan kredit pinjaman untuk nasabah sebagai bersedianya nasabah akan melakukan pinjaman di Bank BRI Unit Cibinong dan penulis juga berkesempatan untuk menghubungi nasabah yang kreditnya sudah bisa dicairkan untuk datang ke Bank BRI unit Cibinong.

4. Minggu Keempat

Pada minggu keempat penulis melakukan kegiatan yang sangat berbeda dengan minggu-minggu sebelumnya yaitu mencari berkas pinjaman yang ada di Bank BRI unit Cibinong sebanyak 200 berkas yang mengalami koleb dan penulis melakukan print rekening Koran nasabah sebanyak 200 yang mengalami koleb.

5. Minggu Kelima

Pada minggu kelima ini penulis seperti biasa melakukan kegiatan yang sebelum nya mengisi buku register realisasi, mengisi buku SKPP, menghubungi nasabah yang akan melakukan pencairan kredit dan juga membuat surat pernyataan kredit untuk nasabah yang bersedia melakukan pinjaman di Bank BRI Unit Cibinong dan yang membedakan dengan minggu sebelumnya adalah penulis berkesempatan untuk menjadi customer service melayani nasabah yang akan mengambil agunan/jaminan nya karena yang bersangkutan telah lunas dalam pembayaran angsuran sebelum mengambil jaminan penulis mengisi buku register pengembalian jaminan dan akan di tanda tangani oleh nasabah yang bersangkutan baru jaminan tersebut boleh diambil oleh nasabah. 


\section{Minggu Keenam}

Pada minggu keenam penulis seperti biasa melakukan kegiatan yang tidak beda jauh dengan minggu-minggu sebelumnya yaitu mengisi buku register realisasi, mengisi buku SKPP, mengubungi nasabah yang akan dicairkan kreditnya dan pada minggu ini penulis melakukan hal yang berbeda yaitu mengisi buku register pelimpahan berkas ke Bank BRI Cabang Cibinong mengisi buku register tersebut bertujuan untuk melimpahkan berkas-berkas pinjaman nasabah kepada Bank BRI cabang Cibinong sebelum dilimpahkan penulis mengisi buku register pelimpahan agar tercatat bahwa berkas ini sudah dilimpahkan.

7. Minggu Ketujuh

Pada minggu ketujuh ini seperti pada minggu-minggu sebelumnya penulis melakukan hal yang biasa dilakukan membuat surat pernyataan kredit, mengisi buku register realisasi, mengisi buku SKPP, mencari berkas pinjaman yang berada di lemari dokumen jadi tidak ada yang membedakan dengan minggu-minggu sebelumnya.

8. Minggu Kedelapan

Penulis pada minggu kedelapan ini melakukan hal yang biasa dilakukan yaitu mengisi buku register realisasi untuk pencairan hari tersebut, mengisi buku SKPP, membuat surat pernyataan kredit karena pada minggu kedelapan ini mendekati akhir bulan cuman sedikit yang melakukan pencairan kredit dan nasabah yang datang ke Bank BRI unit Cibinong cukup sedikit.

9. Minggu Kesembilan

Pada minggu kesembilan ini adalah minggu terakhir penulis melakukan magang di Bank BRI unit cibinong dengan biasa melakukan kegiatan minggu-minggu sebelumnya yaitu melakukan pengisian buku register realisasi, mengisi buku SKPP, hal yang membedakan dengan mingguminggu sebelumnya adalah pada minggu kesembilan ini adalah awal bulan sangat ramai padat banyak nasabah yang mendatangi Bank BRI Unit Cibinong karena dengan lokasi yang strategis jadi banyak ada pencairan kredit sehingga banyak yang harus ditulis di buku register realisasi dan buku SKPP dan setelah itu penulis mengucapkan perpisahan, berpamitan kepada setiap pegawai-pegawai yang berada di Bank BRI unit Cibinong yang sudah membimbing magan penulis hingga waktu magang yang telah selesai. 


\subsection{Perbandingan Teori dan Praktek}

\subsubsection{Strategi Bank BRI unit Cibinong dalam menghimpun Tabungan}

Bank Rakyat Indonesia (BRI) mempunyai kedudukan yang sangat penting sebagai lembaga ekonomi keuangan konvensional di tengah proses pembangunan nasional. Bank BRI merupakan salah satu potensi untuk kembali membangun perekonomian nasional. Banyaknya persaingan dalam dunia perbankan, menuntut Bank BRI unit Cibinong untuk lebih inovatif lagi dalam menciptakan produk-produk yang dapat membantu masyarakat terutama khususnya masyarakat daerah cibinong. Oleh karena itu Bank BRI unit Cibinong harus mempunyai strategi yang dapat menarik minat nasabah untuk menabung atau dihimpun dana nya oleh bank BRI unit cibinong.

Pada Bank BRI unit cibinong disadari perlunya bersaing pada pemasaran produk-produk serta jasa lainnya, sehingga diperlukan strategi pemasaran pada produk dan jasa Bank BRI unit cibinong.

Adapun langkah yang dilakukan Bank BRI unit Cibinong dalam memasarkan produk-produk simpanannya adalah sebagai berikut:

1. Strategi promosi

Suatu produk bermanfaat akan tetapi tidak akan dikenal oleh konsumen, maka produk tersebut tidak diketahui manfaatnya dan mungkin tidak dibeli oleh konsumen, oleh karena itu bank harus berusaha mempengaruhi para konsumen. Untuk menciptakan permintaan atas produk itu, kemudian dipelihara dan dikembangkan usaha tersebut dilakukan melalui kegiatan promosi. Pada kenyataannya media promosi yang berbeda dapat mempengaruhi kesuksesannya penjualan suatu produk, perusahaan mengharapkan kegiatan promosi yang dilakukan adalah untuk meningkatkan tujuan perusahaan dan secara umum tujuan perusahaan yaitu memperoleh keuntungan yang sebesar-besarnya.

Promosi dapat membawa keuntungan baik bagi para produsen maupun konsumen. Keuntungan bagi konsumen ialah konsumen dapat mengatur pengeluarannya menjadi lebih baik, misalnya konsumen membaca iklan ia dapat membeli barang dengan harga lebih murah. Keuntungan bagi produsen ialah promosi dapat menghindari persaingan harga karena konsumen membeli barang karena tertarik dengan mereknya. Promosi bukan 
saja meningkatkan penjualan tetapi juga dapat menstabilkan produksi keuntungan, selanjutnya ialah perusahaan dengan Good Will yang besar akan memperoleh modal dengan mudah. Sebaliknya kerugian bagi produsen adalah konsumen mengharapkan barang-barang yang diproduksi oleh pabrik mempunyai kualitas tetapi kadang-kadang hal ini tidak dapat dipenuhi dan apabila perusahaan sudah mulai dengan usaha tersebut harus dilakukan terus-menerus hingga menyebabkan biaya promosi akan selalu meningkat.

Adapun strategi promosi yang dilakukan Bank BRI unit Cibinong dalam mempromosikan produk-produknya adalah sebagai berikut :

a. Advertising (Periklanan)

Bank BRI unit Cibinong menawarkan berbagai produk-produknya dan keunggulan nya dengan cara menyediakan brosur-brosur yang menarik bagi nasabah yang ingin menghimpun dana nya di Bank BRI unit Cibinong, Segmentasi pasar ditujukan pada umunya kepada masyarakat kecil hingga menengah setiap produk pasti mempunyai brosur yang dapat menarik para nasabah salah satunya itu brosur Tabungan Britama yang dihiasi gambar gambar yang menarik dan slogan "tabungan serba bisa hidup serba mudah" , dijelaskan juga berbagai fasilitas dan kemudahan di dalam brosur produk Tabungan seperti layanan kemudahan dalam transaksi dengan layanan eBanking BRI dan designnya sangat menarik perhatian sehingga para calon nasabah akan melirik produk tersebut dan pada brosur Tabungan Britama junio juga salah satu produk andalan juga menggunakan design yang menarik untuk menghimpun dana dan segmentasi nya tertuju kepada anak-anak banyak gambar-gambar yang menarik perhatian anak yaitu seperti gambar tom jerry, superman dan sweety dan menawarkan kartu debit nya dengan gambar-gambar kartun tersebut dan Tabungan Britama Junio juga mempunyai slogan "Tunjukkan pada anak kalau nabung itu mengasyikan" selain itu pada brosur dijelaskan Tabungan Britama Junio memiliki fasilitas khusus dan menarik untuk mendukung kebutuhan buah hati anda yaitu diantaranya gratis kartu dengan gambar karakter, gratis biaya administrasi, fasilitas e-banking BRI dan fasilitas Installment Saving. 


\section{b. Website BRI}

Dengan website informasi tentang BRI dapat diketahui masyarakat luas sehingga produk-produk BRI seperti tabungan dan juga jasa layanan khususnya produk-produk penghimpunan dana pada bank BRI yang dapat diketahui secara luas oleh masyarakat tanpa harus mendatangi kantor-kantor BRI khususnya kantor BRI unit Cibinong.

c. Publicity (Publisitas)

untuk meningkatkan citra bank di depan para calon nasabah atau nasabahnya melalui kegiatan sponsorhip suatu kegiatan amal, kegiatan sosial atau olahraga. Tujuan dari promosi sendiri adalah menginformasikan, mempengaruhi, dan membujuk serta mengingatkan pelanggan sasaran tentang perusahaan dan bauran pemasarannya jadi Bank BRI Unit Cibinong setiap tahun menjelang hari raya idul fitri akan menggelar acara seperti mudik gratis bagi para nasabah produk-produk BRI terutama juga bagi Nasabah pinjaman acara ini rutin diadakan setahun sekali tujuan dari kegiatan ini adalah untuk menjaga tali silaturahmi terhadap nasabah-nasabah yang sudah mempercayakan dananya dihimpun di bank BRI unit Cibinong sekaligus juga untuk Menginformasikan pasar mengenai produk baru, Memperkenalkan cara pemakaian yang baru dari suatu produk, Menyampaikan perubahan harga kepada pasar, Menjelaskan cara kerja produk, dan menginformasikan jasa-jasa yang disediakan yang terbaru dari produk-produk BRI sehingga nasabah dapat mengetahui info info apa saja yang terbaru dari produk tersebut.

\section{Strategi Alternatif Bank BRI unit Cibinong}

Strategi ini sama saja dengan strategi pemasaran yang dilakukan oleh Bank BRI unit Cibinong ini salah satu strategi yang cukup ampuh untuk menarik minat para nasabah dan meningkatkan jumlah nasabah yang ada di Bank BRI unit Cibinong, seperti diketahui Bank BRI unit Cibinong salah satu bank yang cukup idola yang berdiri sejak tanggal 11 maret 1974 sehingga masyarakat lebih tertarik kepada Bank BRI unit Cibinong.

Adapun langkah-langkah yang dilakukan oleh Bank BRI unit Cibinong dalam menerapkan strategi alternatif adalah sebagai berikut : 
a. Reputasi BRI unit cibinong yang baik dimata masyarakat

Seperti diketahui BRI unit Cibinong sudah berdiri sejak 11 maret 1974 sudah cukup lama beroperasi dari jaman ke jaman sudah mempunyai reputasi yang cukup baik dimata masyarakat cibinong sudah banyak layanan layanan yang cukup lengkap diberikan untuk para nasabah dan setiap harinya selalu ramai dikunjungi oleh para nasabah maupun calon nasabah yang ingin mengetahui tentang produk-produk BRI unit Cibinong.

b. Mantri melakukan berbagai promosi/pemasaran produk

Bank BRI unit Cibinong selalu mempunyai cara-cara tersendiri untuk mengenalkan produk-produk BRI yang ditawarkan kepada para calon nasabah dalam strategi ini setiap sebulan sekali suka diadakan mantra-mantri keliling pasar untuk menawarkan berbagai produkproduk BRI yang berupa tabungan ,deposito maupun pinjaman kepada para pedagang ini merupakan salah satu strategi yang cukup meyakinkan karena secara tidak langsung para mantri melakukan pelayanan terbaik bagi para calon nasabah selain itu biasanya setelah menawarkan produk-produk bank BRI para mantri memberikan souvenir/cinderamata berupa pulpen yang berlogokan Bank BRI dengan motto "melayani dengan setulus hati" dengan motto ini membuktikan bahwa para mantra melayani nasabah dengan tulus sampai melakukan keliling pasar dalam menawarkan produk-produk BRI sehingga dengan adanya strategi ini bisa diharapkan dapatnya meningkat jumlah / minat nasabah untuk dihimpun dananya dan minat nasabah peminjam di bank BRI unit Cibinong, jarang bankbank lain melakukan strategi tersebut.

c. Mengadakan hadiah undian Simpedes dan Beliung Britama

Pada umumnya bank selalu menerapkan strategi tersebut agar minat masyarakat dalam menabung semakin tinggi, selalu tingkatkan saldo Bank BRI unit Cibinong juga menerapkan strategi tersebut yaitu dengan cara mengadakan hadiah undian berhadiah untuk lebih menarik lagi minat masyarakat dalam menabung, Bank BRI sering mengadakan undian hadiah salah satunya dari produk tabungan BRI simpedes hadiah undian ini diadakan setiap setahun 2 kali semakin 
banyak saldo semakin banyak transaksi yang dilakukan semakin besar kesempatan untuk mendapatkan hadiah seperti mobil Nissan march, motor Suzuki, televisi, kulkas dua pintu, dan lain lain selain itu ada hadiah undian beliung Britama sama seperti simpedes berhadiah seperti Mobil, motor, televisi, kulkas, dan lain lain terbukti dengan sampai tahun ini acara undian seperti ini sangat menarik minat masrakat khususnya masyarakat cibinong sehingga selalu diadakan.

d. BRI unit Cibinong memberikan pelayanan yang terbaik

Kepuasan pelayanan merupakan kepuasan tersendiri bagi para nasabah. Ketika mereka mendapatkan pelayanan yang baik di berbagai hal, pastinya calon nasabah akan merasa lebih nyaman untuk bertransaksi. Oleh karena itu bank BRI unit Cibinong sangat memperhatikan pelayanan yang terbaik bagi para nasabahnya maupun calon nasabahnya dililhat dari pelayanan dari satpam, teller, office boy dan khususnya para customer service, untuk memberikan pelayanan yang terbaik BRI mempunyai cukup banyak karyawan terdiri dari 6 teller, 6 Customer Service, 3 petugas keamanan. Diantaranya tidak semua teller dan customer service ditempatkan di Bank BRI unit cibinong, salah satu keunggulan yang dimiliki Bank BRI unit Cibinong itu mempunyai layanan yang namanya teras keliling dijelaskan teras keliling ini adalah layanan yang diberikan Bank BRI unit Cibinong sebagai pelayanan yang cukup ampuh karena dengan menggunakan mobil diubah menjadi bank berjalan karena di dalam teras keliling sudah dilengkapi peralatan yang cukup modern dan canggih di mobil teras keliling sudah ada 1 teller, 1 customer service, dan 1 petugas keamanan. Jadi para nasabah maupun calon nasabah tidak perlu mendatangi kantor Bank BRI unit Cibinong karena setiap hari senin sampai jumat teras keliling siap melayani nasabah, mobil teras keliling BRI akan berkeliling daerah cibinong biasanya setiap hari berbeda lokasi yang akan dituju jam operasional teras keliling BRI dari jam pukul 10.00 wib hingga jam pukul 14.00 wib. Dan BRI unit cibinong satu-satunya Bank unit yang memiliki mobil teras keliling dan itu membuktikan Bank BRI unit Cibinong mempunyai pelayanan yang terbaik. 
e. BRI unit Cibinong menawarkan berbagai kemudahan

Nasabah umumnya membutuhkan pelayanan yang mudah dan aman. Untuk memenuhi kebutuhan konsumen ini, bank bisa menawarkan berbagai fasilitas diantaranya adalah layanan mobile banking atau mungkin online banking. Dari segi ini juga Bank BRI unit Cibinong selalu memberikan yang terbaik dari tahun ke tahun hal ini membuktikan dengan memberikan kemudahan dalam bertransaksi dilengkapi dengan fitur-fitur dan fasilitas yang membuat para nasabah selalu nyaman yaitu dengan adanya Call BRI 14017, Mobile Banking BRI, Internet Banking BRI, dan BRI Mobile yang memberikan manfaat yang praktis, cepat, mudah, dan nyaman bagi para nasabah. Perbedaan nya adalah Call BRI adalah Call Center yang bertugas selama 24 jam untuk menangani keluhan nasabah seperti kehilangan kartu atm biasanya call center ini dilakukan pada saat musibah yang tidak diinginkan, sementara mobile Banking BRI melayani transaksi dalam sms maksimal biaya sms per provider sebesar Rp.1.000, Internet Banking BRI melayani transaksi dengan menggunakan paket internet, dan BRI mobile salah satu aplikasi Banking BRI yang terintegrasi dalam satu menu aplikasi ini bisa dapat di download di smartphone diantara layanan tersebut semuanya melayani dengan fitur yang sama yaitu :

1) Mengetahui info saldo

2) Info DPLK

3) Tarik Tunai

4) Bisa melakukan Transfer antar Rekening BRI

5) Transfer antar Bank-Bank lain

6) Bisa melakukan pembelian pulsa

7) Pembelian tiket Pesawat dan Kereta Api

8) Registrasi seperti registrasi mobile banking, registrasi Internet Banking, dan ganti Pin

9) Melakukan pembayaran Telepon

10) Pembayaran Listrik

11) Pembayaran Kartu Kredit

12) Membayar Angsuran seperti FIF dan OTO 
13) Pembayaran spp kuliah

14) Pembayaran PDAM

15) Pembayaran Pajak seperti PBB, dan PPH Final

16) Pembayaran Asuransi Seperti BPJS Jamsostek, Asuransi Prudential, Jiwasraya

17)Bantuan kemanusiaan seperti Zakat Dompet Dhuafa, Infak / Kurban YBM BRI

18)Pembayaran TV Berlangganan seperti Indovision, Oke Vision, Top TV dan TV Astro

19)Pembayaran pinjaman / angsuran

20) Pinjaman (Loan Type KMK)

\section{1)DPLK (Dana Pensiun Lembaga Keuangan)}

BRI selalu mengedepankan pelayanan-pelayanan bagi nasabahnya dengan motto "Melayani Dengan Setulus Hati" selalu memberikan inovasi-inovasi terbaru agar bank BRI bukan mengejar keuntungan sebesar-besarnya tetapi juga memperhatikan dari segi aspek pelayanan agar kedepannya nasabah kita selalu merasa nyaman dan aman kalau dananya dihimpun di Bank BRI.

f. Strategi Alternatif lainnya

Menurut penulis ini strategi yang paling menjanjikan yang dilakukan oleh BRI unit Cibinong ini kelebihan dari Bank BRI selalu saja ada strategi menghimpun dana untuk meningkatkan jumlah minat nasabah dalam menabung maupun pinjaman strategi alternatif yang dilakukan adalah yaitu dengan cara melalui pinjaman Kredit seperti Pinjaman Kupedes karena langkah yang dilakukan oleh Bank BRI unit Cibinong setelah nasabah mengajukan pinjaman ke Bank BRI unit Cibinong adalah sebagai berikut :

1) Nasabah akan dihubungi oleh pihak Bank BRI setelah disurvey usaha nya oleh mantri bahwa kreditnya sudah dapat bisa dicairkan

2) Selanjutnya besok nasabah mendatangi Bank BRI unit Cibinong dan bertemu dengan Customer Service bagian pinjaman.

3) Setelah itu nasabah sudah menyetujui pinjaman kredit dan telah memenuhi syarat-syarat yang sudah diajukan dari pihak Bank BRI unit Cibinong. 
4) Sesudah itu Customer Service menanyakan kepada nasabah itu apakah sudah mempunyai rekening tabungan di BRI unit Cibinong.

5) Jika nasabah belum mempunyai rekening Tabungan BRI unit Cibinong maka disarankan / dianjurkan oleh Customer Service untuk membuat Tabungan BRI Unit Cibinong.

6) Customer Service akan menjelaskan mengapa harus dianjurkan memiliki rekening Tabungan BRI unit Cibinong karena dengan dianjurkan memiliki rekening Tabungan BRI akan memudahkan nasabah dalam membayar setiap angsuran nya per bulan dalam pinjaman Kredit tidak perlu setoran tunai atau bayar tunai dengan adanya Rekening Tabungan BRI tingkatkan saja saldo di tabungan atau setoran tunai di rekening tabungan BRI otomatis di sistem akan Terdebet biaya angsuran yang akan dibayar sehingga tidak perlu repot-repot membayar tunai, jika angsuran nya sudah lunas rekening Tabungan BRI tersebut bisa digunakan untuk menyimpan dana untuk ditingkatkan lagi saldonya karena Bank BRI mempunyai Banyak Hadiah undian yang menggiurkan bagi nasabah yang mempunyai Rekening Tabungan BRI di Bank BRI unit Cibinong dan nasabah pun merasa nyaman dan aman karena dananya dihimpun di bank khususnya di Bank BRI unit Cibinong.

Strategi memang merupakan bagian yang penting dalam menentukan langkah-langkah tepat dalam mencapai sesuatu, karena tanpa strategi yang jelas akan menyebabkan tidak maksimalnya hasil yang dicapai oleh lembaga. Karena ini sebagai penunjang keberhasilan dalam berbagai kegiatan operasional bank. Dengan strategi tersebut dapat dibuktikan selain meningkatnya jumlah nasabah peminjam strategi ini juga dapat meningkatkan jumlah nasabah penabung dengan adanya strategi tersebut dari tahun ke tahun jumlah nasabah yang dihimpun dananya pun semakin meningkat. 


\subsubsection{Faktor-faktor yang mempengaruhi produk simpanan tabungan pada Bank BRI unit Cibinong}

Untuk mencapai sasaran ada beberapa faktor yang berpengaruh terhadap strategi penghimpunan penghimpunan produk simpanan tabungan pada bank BRI unit Cibinong :

1. Strategi Produk

Produk secara umum diartikan sebagai sesuatu yang dapat memenuhi kebutuhan dan keinginan pelanggan. Artinya apapun wujudnya, selama itu dapat memenuhi keinginan pelanggan dan kebutuhan sebagai produk. Produk-produk yang diinginkan pelanggan baik berwujud maupun yang tidak berwujud adalah produk yang berkualitas artinya produk yang ditawarkan oleh Bank BRI unit Cibinong ke nasabahnya memiliki nilai yang lebih baik dibandingkan dengan produk-produk pesaing. Bank BRI unit Cibinong selalu mengedepankan mutu produk simpanannya sehingga kebutuhan pasar tepat pada sasarannya. Yang dilakukan Bank BRI unit Cibinong adalah dengan syarat-syarat yang mudah dalam pembukaan rekening Tabungan, Deposito, maupun Giro jadi tidak mempersulit nasabahnya untuk dihimpun dananya oleh Bank BRI unit Cibiniong. Adapun strategi produk yang dilakukan Bank BRI unit Cibinong adalah sebagai berikut:

a. Membuat logo dan motto Bank BRI

Logo merupakan ciri khas suatu bank sedangkan motto merupakan serangkaian kata-kata yang berisikan misi dan visi bank dalam melayani masyarakat. Baik logo maupun motto harus dirancang dengan benar. Seperti logo BRI yang sangat sederhana seperti slogan nya yaitu "Melayani Dengan Setulus Hati" yang segmentasinya tertuju pada masyarakat kecil, menengah hingga keatas

b. Menciptakan merek/tampilan produk yang menarik

Untuk berbagai jenis jasa bank ada yang perlu dberikan merek tertentu. Merek merupakan sesuatu untuk mengenal barang atau jasa yang ditawarkan seperti yang dilakukan Bank BRI unit cibinong menciptakan berbagai tampilan produk-produk Bank BRI yang menarik bagi nasabah salah satunya adalah pada produk Tabungan Britama yang dikemas dengan sedemikian rupa yaitu dengan 
menggunakan kartu debit yang bergambarkan Man Of Steel superman ini salah satu tampilan produk Tabungan yang bisa menarik nasabah karena dengan tampilan yang menarik akan meningkatkan minat nasabah dalam menabung dan semakin banyak nasabah yang mempercayakan dananya dihimpun oleh Bank BRI unit Cibinong.

2. Strategi Harga yang ditetapkan BRI unit Cibinong Harga salah satu aspek penting dalam kegiatan pemasaran. Penentuan harga menjadi sangat penting untuk diperhatikan, mengingat harga sangat menentukan laku tidaknya produk dan jasa perbankan. Salah dalam menentukan harga akan berakibat fatal terhadap produk yang ditawarkan. Bagi perbankan terutama Bank BRI unit Cibinong yang berdasarkan prinsip konvensional pasti akan memperhatikan dalam penentuan/penetapan harga-harga produk Bank BRI seperti berikut :

a. Penetapan harga biaya administrasi produk-produk Bank BRI unit Cibinong

Penetapan biaya administrasi sangat penting diperhatikan karena jika bank pesaing menetapkan harga yang lebih murah maka nasabah pun dapat mudah pindah ke bank pesaing ada beberapa penetapan harga biaya administrasi perbulan yang ditetapkan di setiap produk-produk Bank BRI unit Cibinong adalah sebagai berikut :

1) Tabungan Simpedes sebesar Rp.5.500,-

2) Tabungan Britama sebesar Rp.12.000,-

3) Tabungan Britama Bisnis dengan saldo hingga Rp.5.000.000,- lebih biaya administrasi gratis dan kurang dari Rp.5.000.000,- dikenakan sebesar Rp.50.000,-

4) Tabungan Britama junio bundling dikenakan biaya administrasi gratis dan non-bundling dikenakan sebesar Rp.5.000,-

5) Tabungan Simpedes TKI dikenakan sebesar Rp.3.000,Sementara untuk produk-produk Bank BRI unit Cibinong lainnya seperti Deposito BRI, Simpedes Impian, Britama Rencana, dan Tabungan Haji BRI biaya administrasinya gratis, dengan penetapan harga biaya-biaya administrasi ini pada setiap produk-produk Bank BRI unit Cibinong bisa dipastikan dengan harga-harga yang ditetapkan oleh Bank BRI bisa dapat bersaing dengan bank pesaing 
dengan biaya administrasi yang cukup murah dengan fitur-fitur dan fasilitas yang memadai dapat memikat calon nasabah yang akan dihimpun dananya oleh bank BRI unit Cibinong.

b. Penetapan harga tingkat suku bunga setiap produk-produk Bank BRI unit Cibinong

Dalam penetapan harga tingkat suku bunga salah satu merupakan aspek yang sangat penting bagi setiap bank khususnya pada Bank BRI karena nasabah sekarang sudah mulai kritis sudah mulai mengetahui kelebihan-kelebihan produk simpanan tabungan maka dari itu Bank BRI memperhatikan tingkat suku bunga yang ditetapkan dan siap bersaing dengan bank pesaing dalam menghimpun dana nasabah. Adapun beberapa produk Bank BRI unit Cibinong dengan tingkat suku bunga yang berbeda adalah sebagai berikut :

1) Tabungan Simpedes dengan saldo Rp.500.000,- hingga lebih dari Rp.100.000.000,- akan mendapatkan suku bunga antara sebesar $1 \%$ sampai dengan $1,75 \%$.

2) Tabungan Britama dengan saldo Rp.500.000,- hingga lebih dari Rp.1.000.000.000,- akan medapatkan suku bunga antara sebesar $1 \%$ sampai dengan 2,25\%.

3) Tabungan Britama Bisnis dengan saldo Rp.500.000 hingga lebih dari Rp.2.000.000.000,- akan mendapatkan suku bunga antara sebesar $1 \%$ sampai dengan 2,75\%.

4) Tabungan Britama Junio yang Bundling maupun Non-Bundling medapatkan suku bunga yang sama dengan Tabungan Britama yaitu antara sebesar $1 \%$ sampai dengan $2,25 \%$.

5) Tabungan Britama Rencana dengan saldo minimal Rp.100.000 dengan kelipatan Rp.50.000,- dan maksimal sebesar Rp.5.000.000,-, suku bunga yang didapatkan setiap tahun yaitu sebesar 3,25\%/tahun.

6) Tabungan Simpedes Impian dengan saldo minimal Rp.100.000,dan diikutkan dalam undian Simpedes sebanyak 2 kali dalam setahun ini akan mendapatkan suku bunga setiap tahunnya yaitu mendapatkan sebesar 4\%/tahun. 
Produk Tabungan Haji BRI dan Tabungan Simpedes TKI tidak mendapatkan suku bunga apapun. Dengan ini membuktikan bahwa setiap produk-produk BRI memiliki suku bunga yang berbeda-beda dan bunga yang ditawarkan sangat cukup memikat para calon nasabah yang akan dihimpun dananya salah satu contohnya nasabah Bank BRI unit Cibinong yang dari tahun ke tahun mengalami peningkatan dalam pembukaan rekening Tabungan ataupun Deposito.

3. Lokasi BRI unit Cibinong yang strategis

Suatu Perusahaan atau Lembaga Keuangan pasti memperhatikan dari segi lokasi karena lokasi sangat menentukan usaha yang akan dijalani suatu perusahaan. Maka dari itu Bank BRI unit Cibinong ynag berdiri sejak 11 Maret 1974 ini sangat memperhatikan lokasi yang cukup menjanjikan untuk kelangsungan berjalannya suatu usaha. Adapun strategi lokasi yang dilakukan Bank BRI unit Cibinong adalah sebagai berikut :

a. Penempatan lokasi Bank BRi unit Cibinong

Bank BRI unit Cibinong yang terletak di Jl.Raya Bogor Km 45 Cibinong dengan wilayah kerja yang cukup strategis ini membuktikan selalu ramai dikunjungi oleh nasabah BRI maupun calon nasabah karena lokasi nya yang sangat strategis bersebrangan dengan pasar Cibinong dan hanya ada sedikit bank pesaing yang berada di daerah sana jadi membuat Bank BRi unit Cibinong menjadi idola selalu diminati para nasabah maupun calon nasabah.

b. Penempatan automated teller machine (ATM) pada Bank BRI unit Cibinong

Bank BRI unit Cibinong sangat memperhatikan penempatan ATM karena sering banyak terjadi transaksi yang dilakukan oleh nasabah seperti transfer, penarikan tunai dan sebagainya yang berada di kawasan cibinong, banyak nasabah yang mengunjungi ATM pada bank BRI unit Cibinong maka dari itu Bank BRI unit Cibinong menempatkan ATM di depan kantor tepat di depan parkiran motor sehingga lebih efektif, namun kekurangannya adalah hanya terdapat 1 ATM yang berada di Bank BRI unit Cibinong itu yang menjadi kendala sehingga 
sering terjadi antrian di depan parkiran maka dari itu Bank BRI unit Cibinong sudah membangun kembali ATM di depan halaman kantornya terdapat dua ATM yang membedakan dengan ATM sebelumnya ATM tersebut bersifat ramah lingkungan suatu inovasi yang terbaru dari Bank BRI unit Cibinong jadi ATM ini menggunakan energi sistem Tata surya mengandalkan energi dari matahari sehingga hemat dalam penggunaan energi, diharapkan dengan adanya ATM yang dibangun tersebut dapat mengurangi antrian yang sudah sering terjadi di depan parkiran Bank BRI unit Cibinong dan dapat membuat nyaman para nasabah yang telah melakukan transaksi di ATM Bank BRI unit Cibinong.

C. Menempatkan Teras Pasar BRI

Menurut penulis ini strategi yang cukup ampuh atau menjanjikan dilihat dari segi penempatan lokasi nya, jadi Bank BRI unit Cibinong mempunyai Teras Pasar BRI yang ditempatkan di pasar tepatnya berada di pasar Cibinong penempatan lokasi ini termasuk sangat strategis karena seperti diketahui pengunjung pasar Cibinong selalu ramai banyak warga yang beraktivitas disana. Teras BRI pasar Cibinong terdapat 3 karyawan yaitu diantaranya 1 Teller yang siap melayani dalam hal transaksi, 1 Customer Service yang siap melayani dalam hal pembukaan rekening tabungan, deposito dan 1 penjaga keamanan yang siap menjaga keamanan di sekitar Teras Pasar BRI agar tidak terjadi suatu hal yang diinginkan, dan kerja jam operasional Teras Pasar BRI itu dimulai dari jam 10.00 WIB s/d 14.00 WIB. Dengan adanya Teras Pasar BRI pedagang atau pembeli tidak perlu jauh-jauh mendatangi kantor Bank BRI unit Cibinong tetapi bisa langsung mendatangi Teras Pasar BRI dalam hal transfer, pembukaan rekening dan sebagainya. Menurut penulis Bank BRI unit Cibinong telah melakukan yang terbaik bagi nasabahnya karena Teras Pasar BRI selalu ramai didatangi oleh para pedagang maupun pengunjung pasar pada sekitar pukul 11.00 WIB s/d 13.00 WIB. Dengan penempatan Teras Pasar BRI akan semakin banyak dana yang akan dihimpun oleh Bank BRI unit Cibinong. 


\section{BAB IV \\ SIMPULAN DAN SARAN}

\subsection{Kesimpulan}

Berdasarkan hasil pembahasan penulis menarik beberapa kesimpulan, antara lain :

1. Strategi pemasaran dan strategi alternatif Bank BRI unit Cibinong.

Pada Bank BRI unit Cibinong, disadari perlunya bersaing pada pemasaran produk-produk serta jasa layanannya sehingga diperlukan strategi pemasaran pada produk dan jasa Bank BRI unit Cibinong. Dan dana pihak ketiga merupakan sumber pendanaan yang utama/penting Bank BRI unit Cibinong khususnya pada produk simpanan tabungan. Bank BRI unit Cibinongn menawarkan berbagai kemudahan dalam berbagai transaksi di Bank BRI seperti fasilitas-fasilitas yang dinikmati oleh nasabah yang ingin dengan cara mudah dan cepat yaitu dengan BRI Mobile Banking, Internet Banking, dan Call BRI tanpa harus mendatangi kantor Bank BRI terdekat, Kedelapan yaitu melalui pemberian pinjaman ini salah satu strategi alternatif yang cukup menjanjikan karena jika kredit sudah dicairkan nasabah dipastikan harus membuka rekening simpanan karena akan lebih mudah dan praktis jika membayar angsuran melalui rekening simpanan yang otomatis akan terdebet oleh sistem dan ini juga salah satu strategi meningkatkan minat nasabah dalam menabung.

2. Faktor-faktor yang mempengaruhi strategi penghimpunan produk simpanan tabungan pada Bank BRI unit Cibinong.

Untuk mencapai sasaran ada beberapa faktor yang berpengaruh terhadap strategi penghimpunan produk simpanan tabungan, diantaranya yaitu :

a. Strategi produk

Penerapan strategi pemasaran berbagai produk simpanan yang dilakukan Bank BRI unit Cibinong adalah mengedepankan mutu dari setiap produk simpanannya sehingga kebutuhan pasar tepat pada sasarannya. Dengan membuat kemasan tampilan yang menarik bagi nasabah yaitu salah satunya dengan BRI Man of Steel tampilan yang dapat menarik minat nasabah menciptakan produk yang mudah dikenal. 
b. Strategi harga

Dalam penetapan harga harus sangat diperhatikan oleh Bank BRI unit Cibinong agar bisa bersaing denga bank-bank yang lain seperti dalam hal penetapan harga biaya administrasi dari setiap produk simpanan tabungan BRI yaitu berkisar antara Rp.3.000,- s/d Rp.50.000,- dan juga dalam hal penetapan harga tingkat suku bunga diberikan sebesar antara $1 \%$ s/d 7\% pada produk-produk simpanan BRI seperti Tabungan BRI. Dengan adanya penetapan harga yang sudah ditetapkan diharapkan dapat lebih banyak lagi menarik minat nasabah yang ingin menyimpan dananya pada Bank BRI khususnya Bank BRI unit Cibinong.

c. Strategi Lokasi

Penempatan lokasi kantor Bank BRI unit Cibinong sangat strategis karena letaknya yang berada di pinggir jalan raya yang sering dilalui kendaraan dan berdekatan dengan daerah pasar sehingga kantor Bank BRI unit Cibinong selalu ramai oleh pengunjung/nasabah selain itu ditempatkannya beberapa ATM yang berada di lingkungan Bank BRI unit Cibinong dan ditempatkan ATM bertenaga surya yang ramah lingkungan agar dapat lebih membuat nyaman para nasabah dalam hal bertransaksi. BRI unit Cibinong juga menempatkan Teras Pasar yang letaknya berada di pasar Cibinong jadi untuk para pedagang atau pembeli di pasar tidak perlu mendatangi kantor BRI unit Cibinong jika ada keperluan.

\subsection{Saran}

Adapun saran yang penulis sampaikan dalam kegiatan praktek kerja lapangan pada Bank BRI unit Cibinong, dalam persaingan yang semakin ketat banyak lembaga keuangan seperti bank berlomba-lomba untuk menarik minat nasabah dengan berbagai strategi-strategi yang di miliki bank tersebut, tentu ini membuat Bank BRI harus menciptakan inovasi baru dalam menarik minat nasabah seperti meningkatkan jaringan untuk memudahkan nasabah dalam bertransaksi, maka diharapkan bagi Bank BRI unit Cibinong untuk lebih meningkatkan kembali kinerjanya dalam memasarkan dan mengembangkan produk-produk yang sudah ada. 


\section{DAFTAR PUSTAKA}

Assauri, Sofjan. 2013. Manajemen Pemasaran. Jakarta. Rajawali Pers.

Fred R David. 2013. Manajemen Strategis. Edisi bahasa Indonesia. Jakarta. PT. Index Kelompok Gramedia.

Ikatan Bankir Indonesia. 2013. Memahami Bisnis Bank, PT Gramedia Pustaka Utama, Jakarta.

Iskandar, Syamsu. 2013. Bank dan Lembaga Keuangan Lainnya Edisi Kedua. Jakarta. IN MEDIA.

Kasmir. 2014. Bank dan Lembaga Keuangan Lainnya Edisi Revisi 14, PT Raja Grafindo Persada, Jakarta.

Mintardjo. 2013. Administrasi Bank Manual Operasional Kantor Cabang, Erlangga, Jakarta.

Pandia, Frianto. 2012. Manajemen Dana dan Kesehatan Bank. Jakarta. Rineka Cipta.

Wardiah, Mia Lasmi. 2013. Dasar - Dasar Perbankan, Pustaka Setia, Bandung.

Nurendah, Y. and Mulyana, M., 2013. Analisis Pengaruh Kualitas Pelayanan

Perpustakaan Terhadap Kepuasan dan Hubungannya dengan Loyalitas Mahasiswa.

Jurnal Ilmiah Manajemen Kesatuan, 1(1), pp.91-105.

Mubarak, M.M., 2009. ANALISIS ASOSIASI MEREK DAN PENGARUHNYA PADA KEPUTUSAN PEMBELIAN KONSUMEN Studi Kasus pada Ramayana Department Store-BTM. Jurnal Ilmiah Ranggagading (JIR), 9(1), pp.45-55.

Sad, R.I. and Sukartaatmadja, I., 2013. Pengaruh Atribut Produk Herbal Terhadap Kepuasan Pelanggan. Jurnal Ilmiah Manajemen Kesatuan, 1 (3).

Sujana, S., 2001. Analisis Antrian Pada Teller: Study Kasus Pada Bank Rakyat Indonesia (BRI) Bogor. Jurnal Ilmiah Ranggagading (JIR) Nomor, 1(2), pp.61-69.

Sujana, S., Zuhdi, S. and Kamaludin, K., 2006. Formulasi Strategi Pengembangan Jaringan Distribusi terhadap Tingkat Volume Penjualan: Studi Kasus pada PT Hero Supermarket. Jurnal Ilmiah Ranggagading (JIR), 6(2), pp.104-109.

Zuhdi, S. and Yudi, D., 2008. ANALISIS BRAND LOYALTY TERHADAP KEPUTUSAN PEMBELIAN Studi Kasus Pengguna Mobil Merek TOYOTA Pada PT. Setiajaya Mobilindo Bogor. Jurnal Ilmiah Kesatuan Nomor, 10(97), p.2.

Priyanto, R.E., Rosa, E.S. and Syarif, R., 2014. Pengaruh Personal Selling dan Kualitas Produk Terhadap Keputusan Pembelian. Jurnal IImiah Manajemen Kesatuan, 2(1), pp.119-128.

Widjojo, A.S. and Suardy, W., 2009. Analisis Strategi Pelayanan Oleh Front Liner Dan Pengaruhnya Terhadap Kepuasan Nasabah Pada PT BANK Central Asia Tbk Capen Mayor Oking. Jurnal IImiah Kesatuan Nomor, 2.

Supriyani, E. and Bintang Sahala, M., 2014. Pengaruh Tata Letak Terhadap Kepuasan Pelanggan Ritel. Jurnal Ilmiah Manajemen. Diakses, 22.

Yanuar, D. and Rosita, I., 2013. Studi komparatif sistem bagi hasil pembiayaan mudharabah dan sistem bunga kredit pinjaman (Comparative study Mudharabah sharing system and the system interest rate loan). Jurnal IImiah Akuntansi Kesatuan, 1(3), pp.215-220.

Kurtubi, A. and Pramiudi, U., 2014. Pengaruh Informasi Arus Kas terhadap Return Saham Perusahaan Studi Kasus Pada Perusahaan Yang Tercatat Di Bei Pada Indeks LQ45. Jurnal IImiah Akuntansi Kesatuan, 2(1), pp.047-058. 
Gustini, T. and Efrianti, D., 2013. Peranan Penerapan Sistem Persediaan Just In Time Terhadap Hasil Produksi. 